のにんこ会し容

二出でなの棓て易

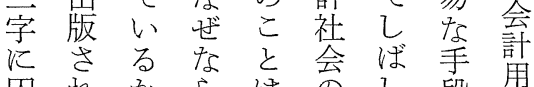

囚れから、格公段語

はたら、、外ばで語—

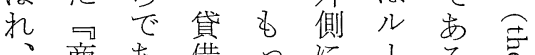

、商あ 借る

貸活。照もん㳻品借

借用事表ポで使 5 怘対

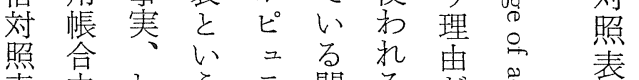

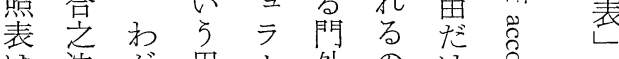

は法肪用l外の将主子

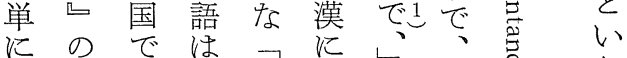

他共貸、貸は会一枩

人著借そ借ま誈種は用

と者対の 対っ 訪の社特語

の 磯照字照た社会特 ゙゙洙

間村表 面表通会殊 涪方

の音々加し 通住社会 ラ

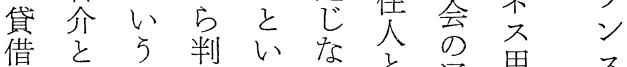

借々 齐用䉼

又藤語し 角が方角語語

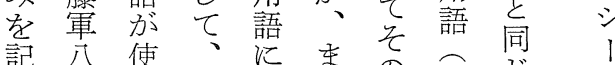

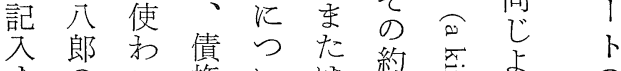

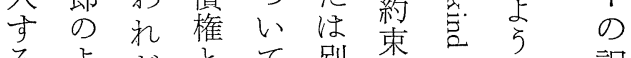

るよだ とて 別㕝虽に訳

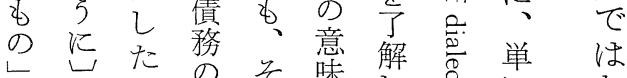

乞相当対 の

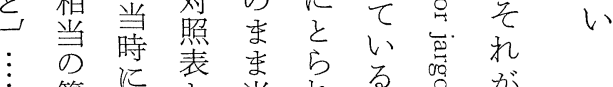

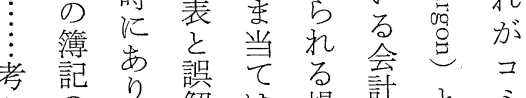

光のて解は場鮊とミ

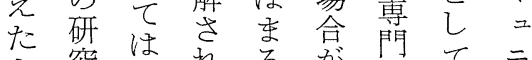

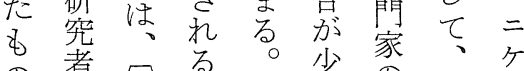

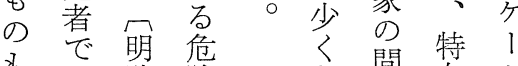

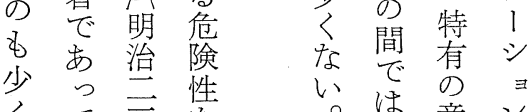

くて 三告多通意ン

高

なる 年多年通味の

か、二分比をた

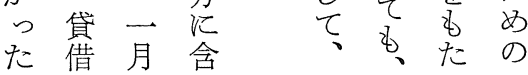

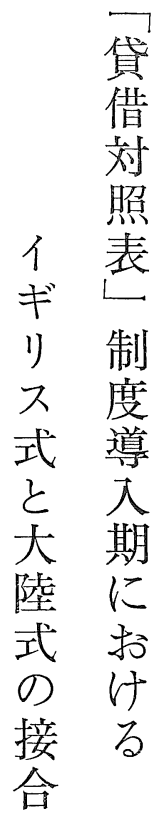

卖

貞

斗 
経 営史学

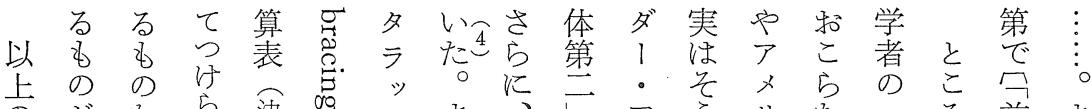

の が な兄 決

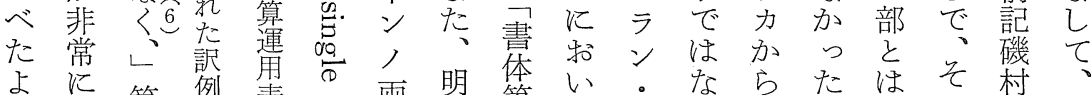

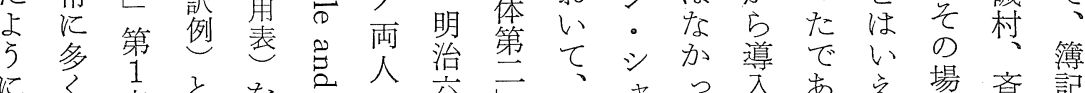

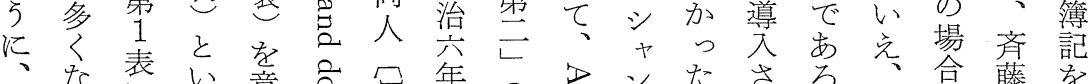

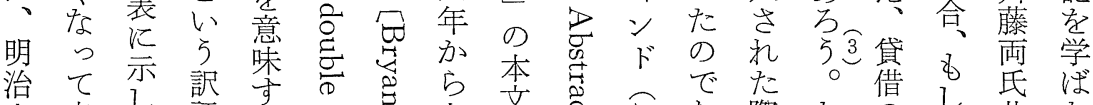

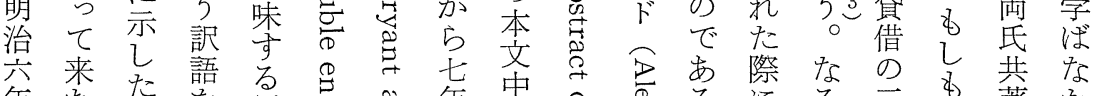

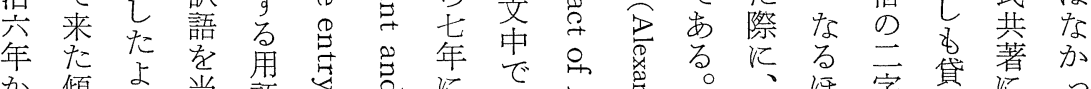

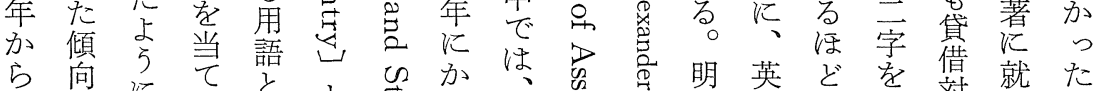

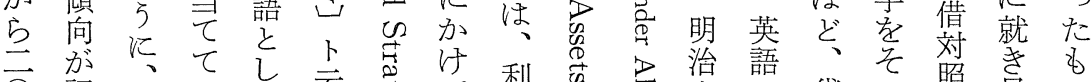

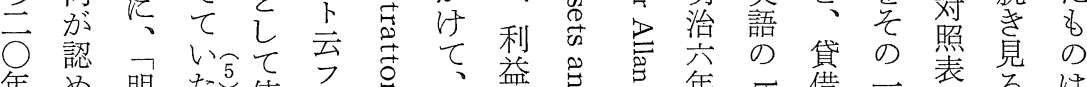

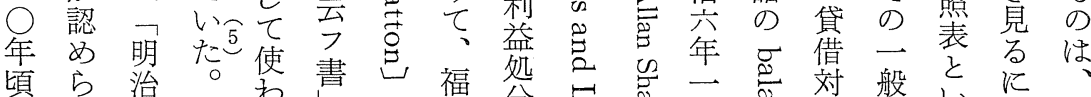

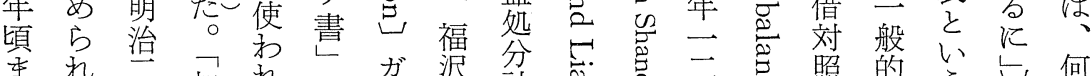

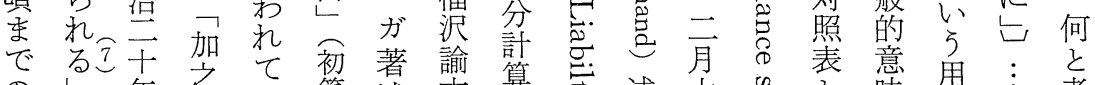

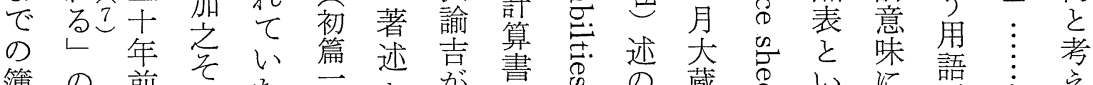

簿の 前れ た

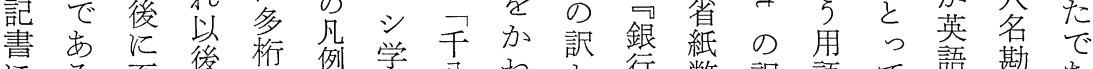

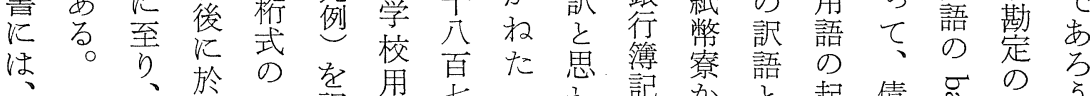

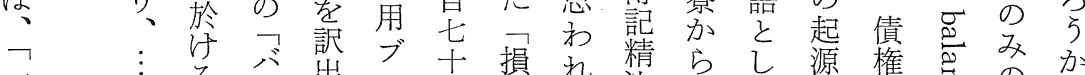

子

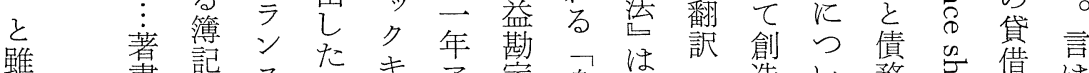

蛙 書 畫ス可

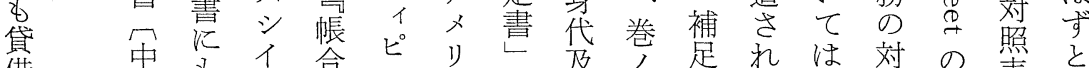

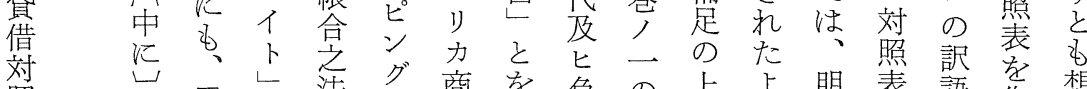

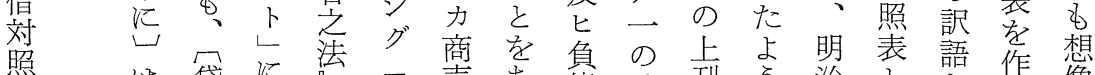

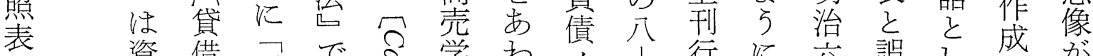

な 資借平でミ学わ文行に六誤し成㤎

る 産 対 均

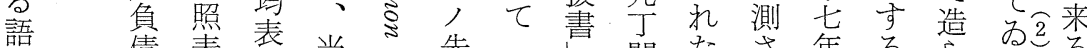

を㥽 表衣当ら先省間たさ年るららる

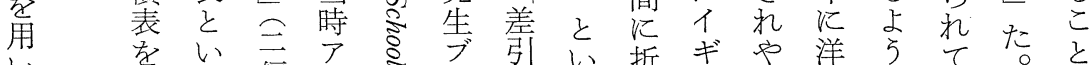

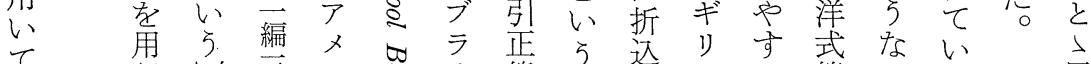

て 居 語

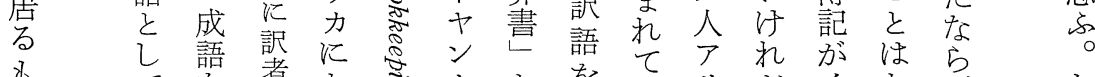

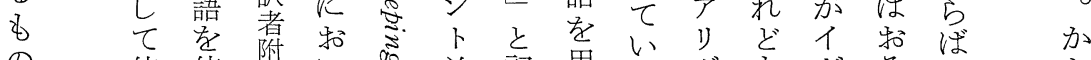

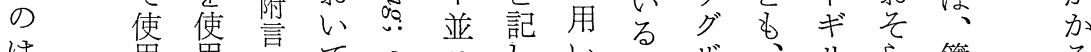

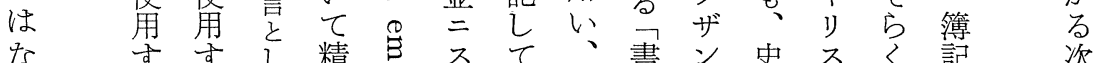


第 1 表 簿記書に括ける ${ }^{\mathrm{B}} / \mathrm{s}$ の名称

\begin{tabular}{|c|c|c|c|}
\hline 訳者または著者 & 書 & 発行年月 & $\mathrm{B} / \mathrm{S}$ の 名 \\
\hline 大蔵省紙幣寮 & 銀 行 簿 記 精 法 & $\begin{array}{l}\text { 明治 } \text { 年 }{ }^{\text {月 }} \\
6.12\end{array}$ & 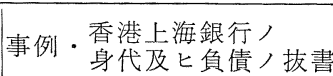 \\
\hline 福 沢 諭 吉 & 帳 合 之 法 (二) & 7. 6 & （平 \\
\hline 小林 儀 秀 & 馬耳蘇氏複式記簿法 & 9. 9 & 本 財 并 借財正算表 \\
\hline 加 藤 & 商 家 必 用 (二) & 10. 4 & 引 見 認 \\
\hline $\left.\begin{array}{ccc}\text { 森 } & \text { 岩 楠 } \\
\text { 森 } & \text { 島 } & \text { 修太郎 }\end{array}\right\}$ & 簿 記 学 階 梯 & 11.10 & 有物 及負債 表 \\
\hline 秋 元 晋 & 簿 記 法 独 学 び & 12. 5 & 有金 及借金実算表 \\
\hline 山田 十畧 & 人民必携簿記 提要 & 13. 4 & 資 産 \\
\hline 土肥 謙 吉 & 簿 記 法 独 案 内 & (改訂) 16.8 & 資 産 及負 債 表 \\
\hline 竹 田 等 & 校訂・商用簿 記 学 & 15. 6 & 産真 \\
\hline 森 下・森 島 & 民 間 簿 記 & 17. 8 & 有物負 債 平均表 \\
\hline 青 柳 源十郎 & 簿 記 学 独 習 & 19. 6 & 物 \\
\hline 飯 塚 栄太郎 & 新 択 商用簿記 独学 & 20. 9 & 産 \\
\hline 藤 井 改 造 & 普通商業簿記手引草 & 20. 4 & 産 \\
\hline 勝 村 栄之助 & 商 用 簿 記 学 原 論 & 22. 6 & 負 \\
\hline
\end{tabular}

第 2表 営業報告書に和ける ${ }^{\mathrm{B}} / \mathrm{s}$ の名称

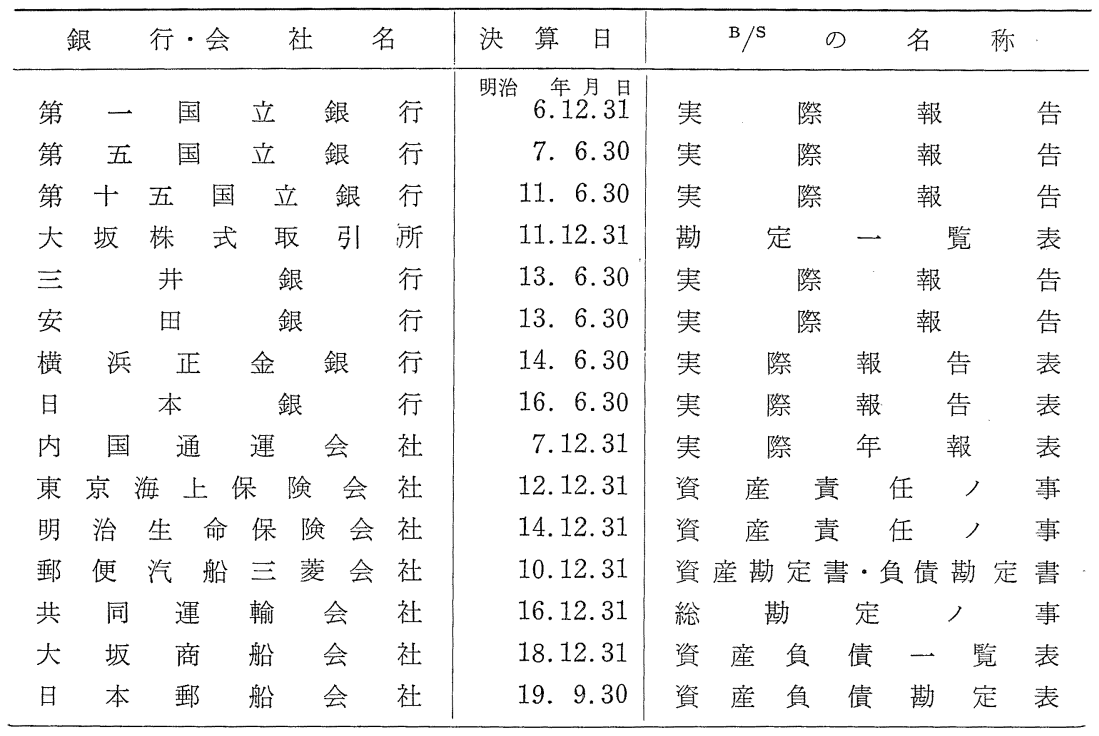


あ学が治とたか か

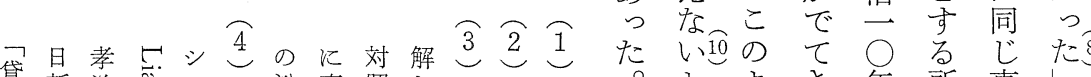
貸新治总=沿直照し

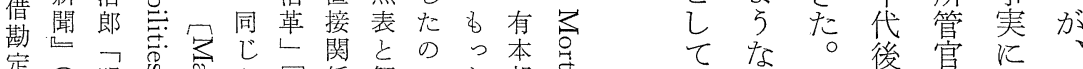

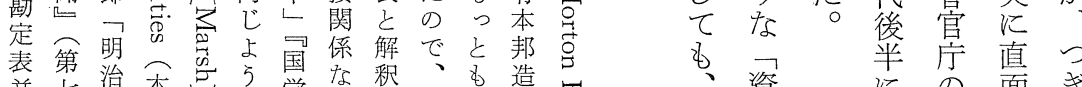

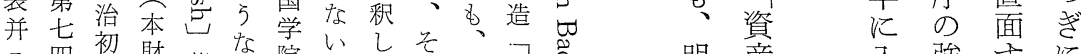

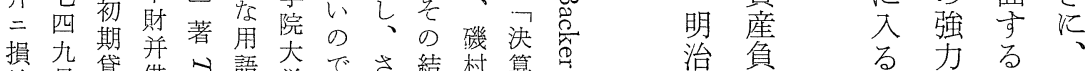
益号貸借凹語大学さ結村算の

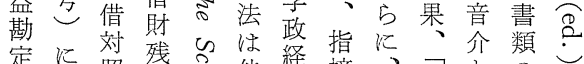

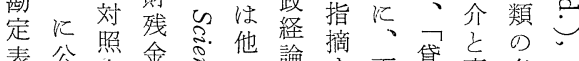
表公表金怘に論摘両貸斎名心

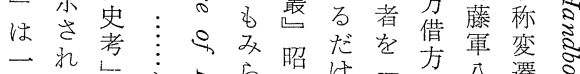
括た鸟るら和江姜方公遷す

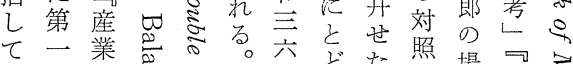
て国経莺田た年め表場会る゙

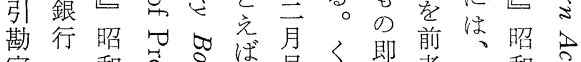

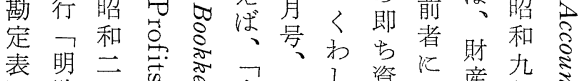

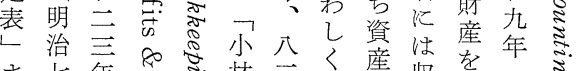

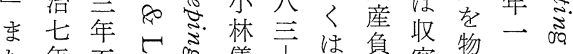

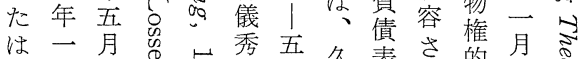

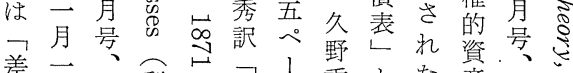

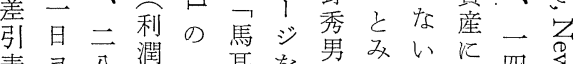

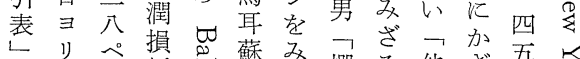

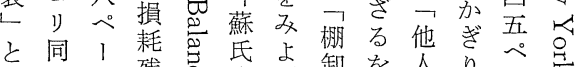

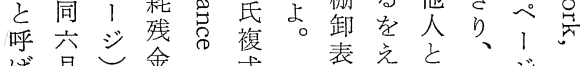

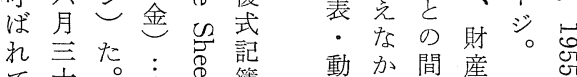

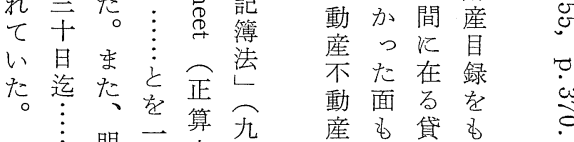

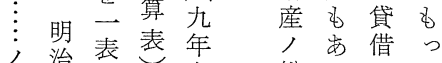

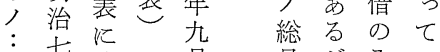
交連は月目がみフ 第七衫刊録、を動

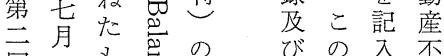

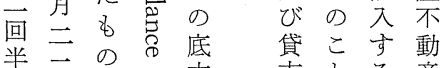
季三百吕本方亡る産 報日要年借はしの 告の要点 $\dot{C}$ 方当債総 で東西昰 京西。照考務 治 筫 ○表 年 で用のた青䍃 の語 場 分当報 簿 統 合 い時告 記一 乙 設書 書化 同実立上 営過程 第報 れ 公 報に2 告国さ 告、表禾立れ 畫はなた

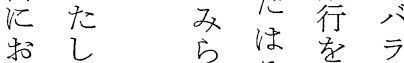
いて れと标ン て政るれじス は府よにめ。

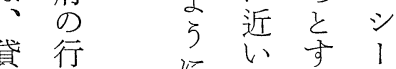
貸行政㳻名 る 対指 称各の 照導資を種名 表㤎産統の称 之表少 負一銀に い入 債し行つ 用て 表无会い 語いにい請調 をた類て 、査 使が尃い当方

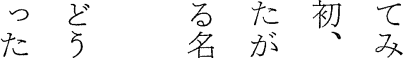
事加称、大 例 ほ を 蔵と は皆概 使孞省 無に傾、中れ でい向明心年 


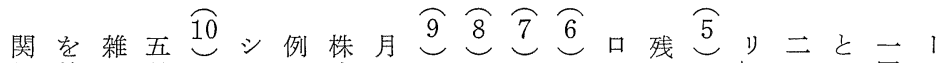
係統誌月目式に品し

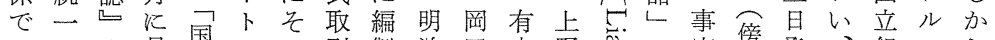
はしや昇立にい引製治田本野总棚実点発さ銀レし、

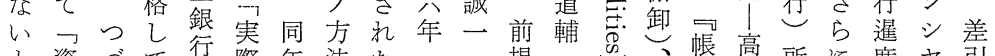
と資らて行際年法たー、揭学、帳高所飞度ヤ引 乙産い銀報報九 $ヨ \neg$ 一貸論新し 名合取 氏 七負て行告告月制国月借文稿負名之法子分虽報卜々

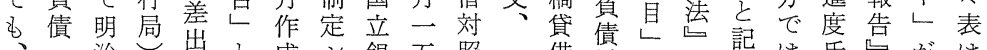

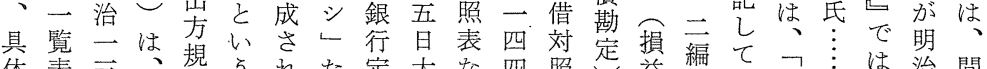

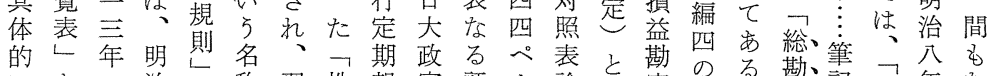

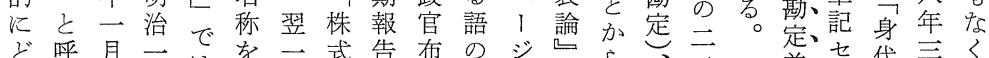

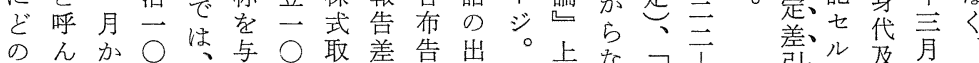

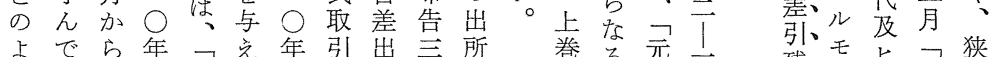
よでら年 ᄀ党年引出至所巻る元引残、モ七つ狭

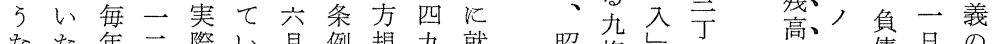
なた年二際い月例規九就昭桁七間向二債日の

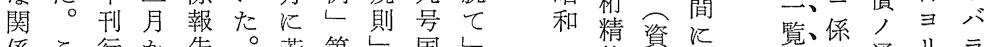
係こ行か告。若第尗国し がのしらし あこた一と っと口年以 た と銀余 5 加明行に名 明治課わ称 確一つたか に○局り用

乙年 、 壳代年銀 5 な後次行れ か半報理て っ $k$ 告論 た拈しとた けに実に る揭務电 $\neg$ 載の か 資し普加 産た及的 負各雑 占 債銀誌ず 表行之。 と取し大 い所、省 弓 の 毎 銀 用 バ月行 語 ラ 発 課 のン行普ス

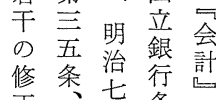
正つ年条昭 ないでに和 さで月も年 た治三方六 国年旦さ号 銀月公宫が五 行一官国五 報日告最! 一算本折 旨表主込 年で勘ま 二 定机 辛。

友・た治

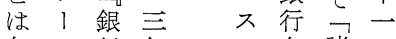
無卜行年・条諸三

出官 $\overrightarrow{0}$ 銀 方布行 嫢告号財 唄第亡諸 は、六表規 い号わ則 ず つ加と 攻国 ᄂ 专正 は明 ラ゙国じ治 ン銀了年
表、ル通り ラ ロ或同ン

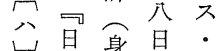
毎本代マシ \begin{tabular}{llll} 
月最主合 & ゲ \\
\hline
\end{tabular} 最銀䛨古の 後行及東 2 点平 営事務倩第指 表業取筫向 川灾 云方合 立用

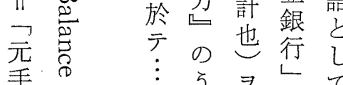

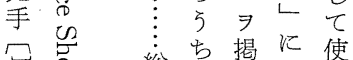

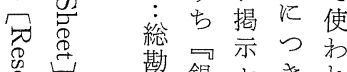
点定銀七きれ 号は 差雑差、検よ ᄂ 平 引誌引、查 万 资均 归第亭後に 産 之第 高、後な 勘改転 号 定乃 定へ記 表手た な試算治令載た び 表 ル 一 傍 に、覧年! 高た 、゙、 払入代表二苘伺第 
対 三一儿第草句いし 語 明

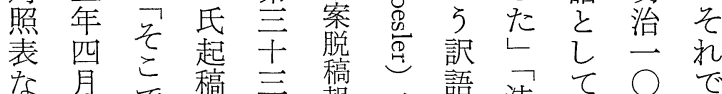

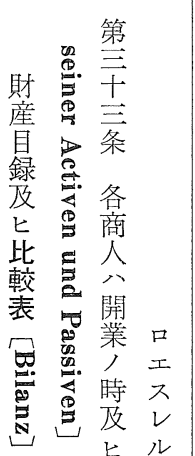

る云で稿桑報が語法かて年は

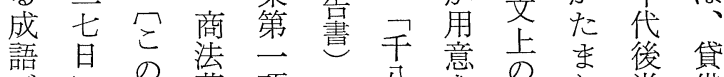

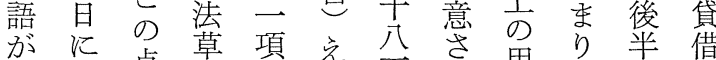

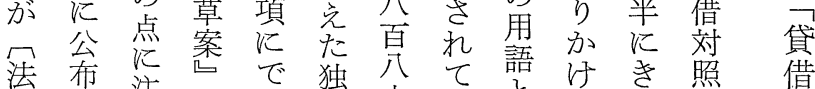

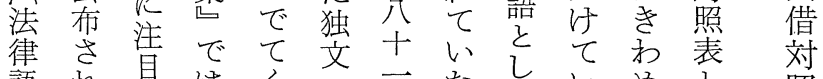

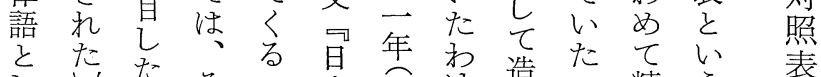

こ た た そ た

Э 9 爾 氏

製製後起

ス両毎稿

ル車翌商

時 严法

総 引三案

厂 別月

, 冊以

商人帳内

品帳 二

及簿動

要記産

権入動

利シ動

并 テ 座

二署

其名総

他 其

総へ録

テシ并

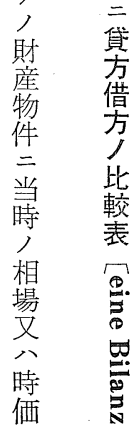

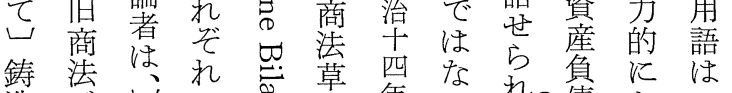

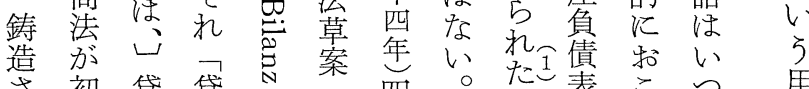

さ初貸貸会。四。た表こつ, 用

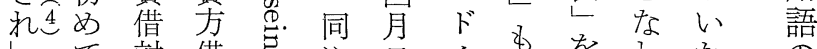

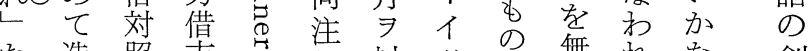

た造照方今解以ッ兴無れな 創

のっ表うる解示人を゙視たる。出

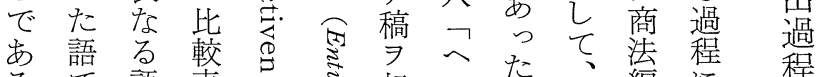

るで語表る怘起ルだ、編に程

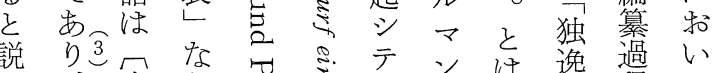

いレ商ら

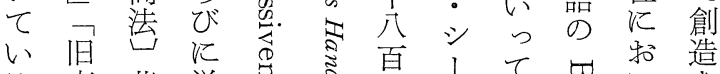

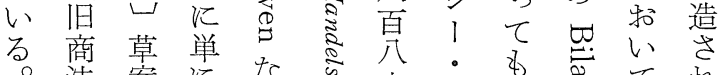

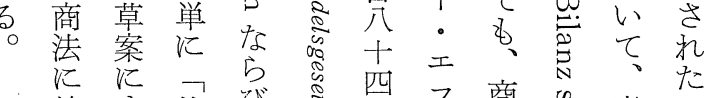

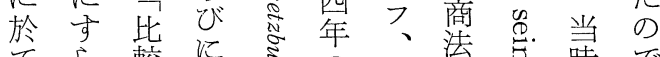

て 5 較第空㫜口編怘時で

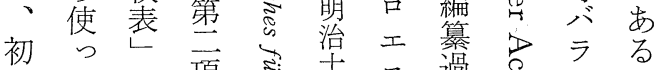

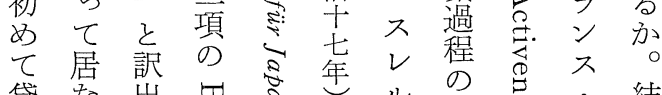

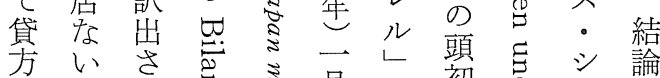

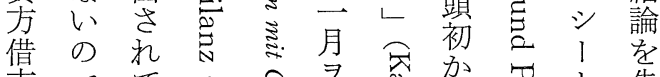

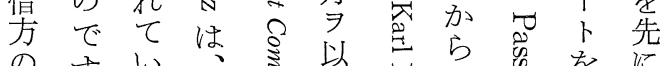

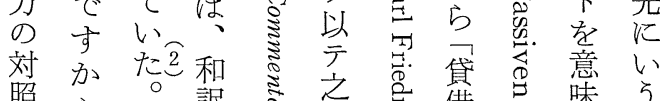

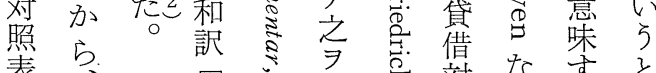

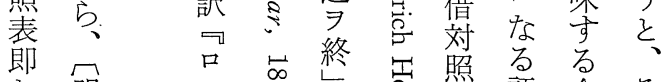

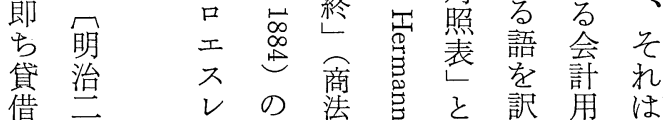

借三レの法喜と訳用は 
二七以士揭年采た年い

揭年テ三禾狍商 5 右

ク七此条ずレ社

ル月二と、商法方語み

ᄂ三之同口社

上三今様口法 会口使狆

ナ日略沓草社工わる

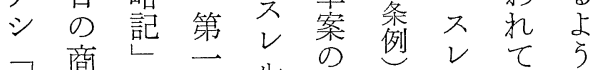

規社し 項氏審がルいに

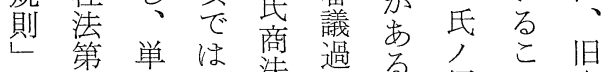

ヨーに一草程の編と商

只読公貸暮去で纂は法

替会比方委、、シた第

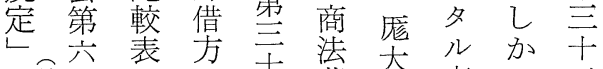

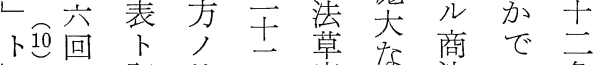

修特記继条案第商草る 第

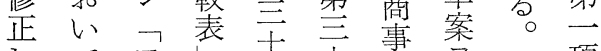

してアし三会寻し項

たはクと齐齐社基加に

に、チい条条桑礎加は

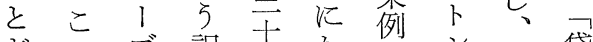

ま゙すブ、訳四か 編シかわ貸

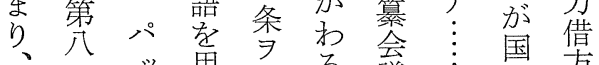

己十ッ用合る 各議編商了

貸分 1 条并条筆編商対

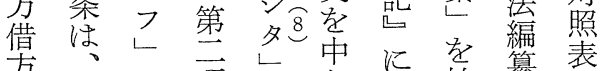

方第 冠貢商心热始篡表

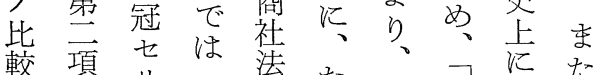

較項サっ草た沈た

表中先草ぞロ十悼

な ᄀレ 案っエ杂第っの

ら配略 貸分第正語

び当語方借十るるル年法項

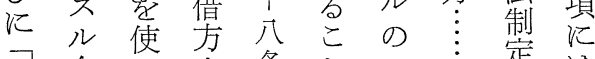

比会口条と烄三定は

較社て

表毎た較商よ草! 佉昔

乙半㤎表法 5 案 $\vdots$ 対

い年、下草。文明照

5 二明ア案 $\Rightarrow$ 議治表

反 項

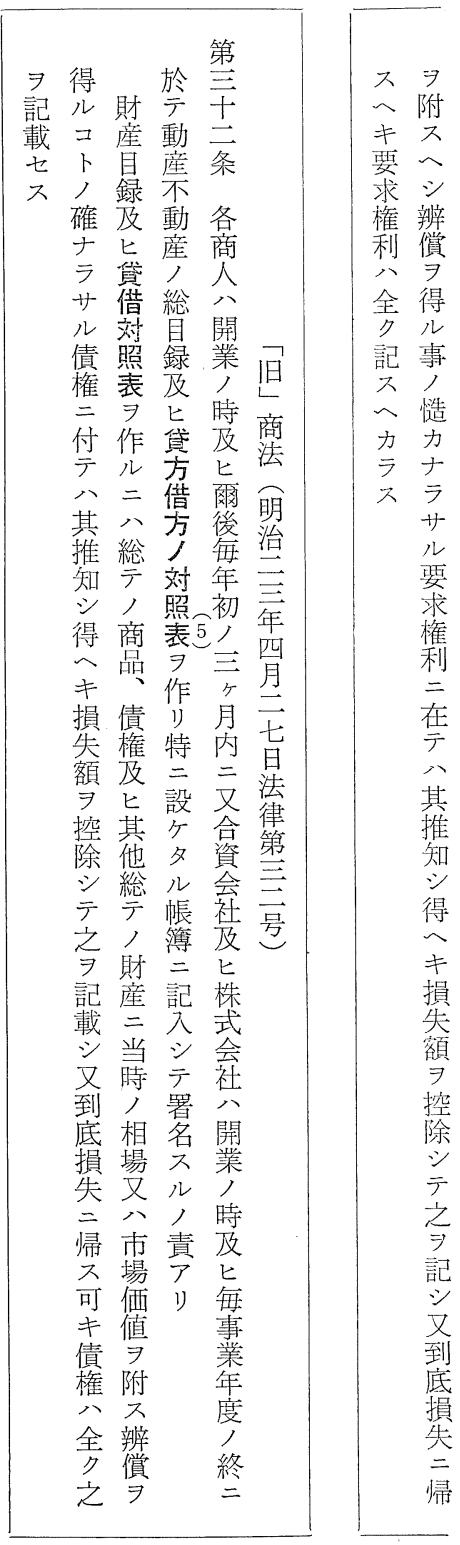


第 表 第

読々回文

会改飞結

第 め提 果

二

回㷛苜さ

でまたの

独京法社

逸商社涬

墽尼案

法第貸第

云会借十

八社, 分

条江紫

精子軗第

神及立

ヨ七な五

採し ら゙条

淿化組

及․․

本飞䘡か

第な㝨点

干等は柷

五嵒貞

各㘯明

条方治

左记方公

盟了年

如治対 六

焂㖕量

年年文

セ㠿な 日

ラ月らの

レ二 び 商

タ皇八飞社

日 法

の 貸 第

商 借

社対 読

法 照 会
乙 社

訳

た条と

の 例こ

で編 ろ

本 香

条賲治

八買

左が公

如比年

些紫

蓚軗亲

セ計の

亏 算 商

合表 社

為第

, 勘 会

義定修

務 $尹$ 正

学暮

者財案

下産

页目

其 録

公及

喤傗

分借

取 照

締 表

役包

検兽

查鼠

学

署紐

多テ

天 検

シ查

,

検

查

受

且

為

分 読

又会

貸。四

借。八

対。回

照・で

表第

也 百

公

何分

傍害

点 議

亭祭

寺元

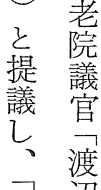

後辺

段洪

決13 基

決全

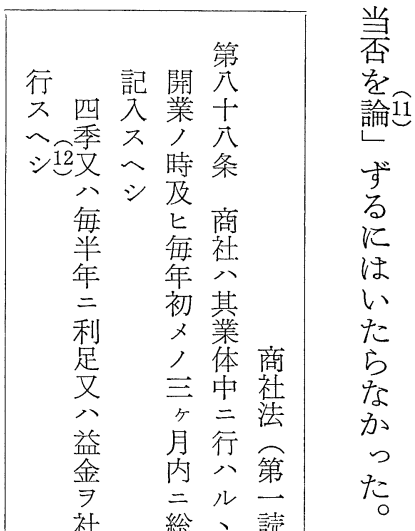

筫総、䛃

二 産例修

配

目徒

録七草

并商案

会 二業

社貸帳

六簿

毎借

半方設

比紛

前 較

項表業

二 $\quad$ 務

揭製取

ク シ 扱

ル 財画上

産力事

目 ラ 件

録㝑

七力載

比為

皎メル

袁二ノ

二 設義

係ケ務

ル タ

規儿リ

定帳卜

履 簿 ス 
奏

セ望右

டの

ら 調

犯查

た委

比員

的報

加告

か案

わ蛙

ら 明

ず、治

公九

布 年

さ六

れ

な 三

か 二

○日

たの

が 元

高老

の 商

影 社

響 法

は 第

す 二

ぐ

あ 言

ら 讜

わ会

机

た 確

た定

と 議

壳

崶為

翌さ

示和

年た

石た

川

惟

安上
修読為な灵初々

正芐設特当て

$\vdots$ 付 ラ 坖

益机夕老内䂞季委五

金たル完二条六尔

$\ni$ が賛会

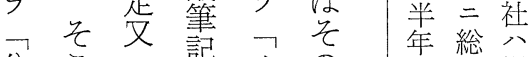

分こ公記了のの総帳

配で其飞終玉財鏟簿

金選業化少産, 7 商

$=$ 二 為商

利記 モx社

息入, 二法

臭不設

公可不学

分シ又ラ老

配開 $v$ 院

金業夕严

ラ ノル調

社時 規 查

員定報

二 毎又告

配年爸

当度 其

又, 業

儿終 体

会证,

社 二 惯

公於 例

毎 $\bar{\nearrow}=$

半総従

年財化

二 産帳

財, 簿

産目

目 録 備

並

其

貸商

方 業

借及

方財

詨産

対,

製照現

シ 表 状

前 $\quad \exists$

項製 明

学知

規共シ

定之得

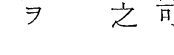

出体る立琞

卜さと慣と於治

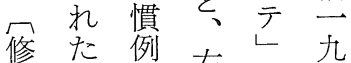

正志右二年

㤎名従商 引 三

為芑調 ᄂ 社之号

查々法別 百

さ委い第冊の

れ員 方忽と商

た に文・向社

上句四 7 法

り $\exists$ 溒马第

下运錐之主

付正力四

原で草為読

案 明案

第治 第 設

九条方回

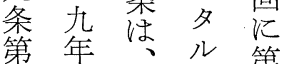

第一第

項合会二杂

頁 一社 改全子

四旦公斿

季のの 5 て

- 元 つ机提

э老ぎた出

毎旁容机

無法 其業

月第体
貝備社

貸三商第

借貸業严

読

照 借財会

表方産䩦

裴対現正

シ照状草

前表 $\exists$ 案

項 $\ni$ 明

製 知

規 シ シ

定共得

和

履之キ

行 $v$ 記

可て別 7

, ᄌ

帳

簿 義

= 務

記 ア

入ル

ス モ

可,

シ ト

ス

開

業

時

及

年

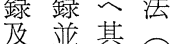




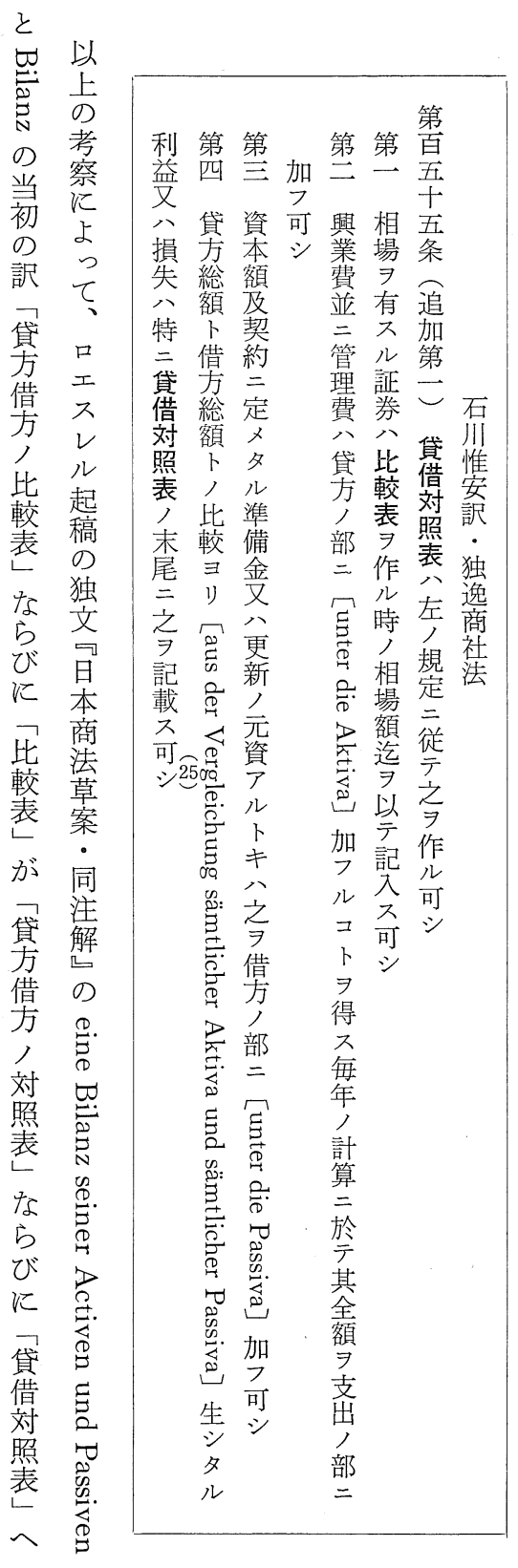

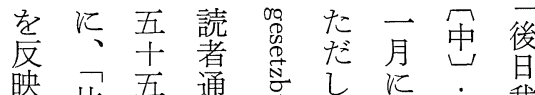
映比吾通営し、に

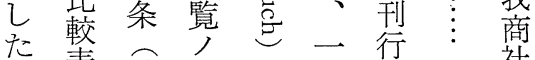
先表追便分行社

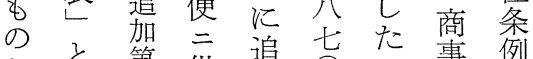
文訳第供補年独会, る出こ学さ的逸社発 そ机な為た第商係乃 がてっ仮第次法ルル でいてり百株全時 き它い三旦式で部彼 る゙こる第市改は翻此 あこ条条法怘訳参

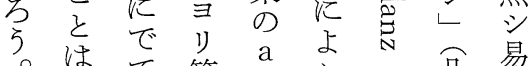
商第 社面白訳傑吕 法当八、ら語、シ 菖主士原た交会台 譒哭条普分社条為 過总為通六法編務 程 飞の凡法年用委テ 打 5 集第年語貝我 占分二法でカ る番た吾般にあ現 比首た条ドたた法

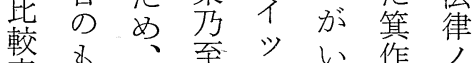
表もこ至商い作語 かたこ云法貸祥詞 らけで百后昔の二

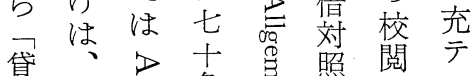

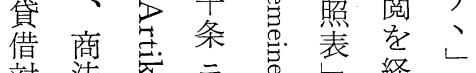
対法寅二索経 ᄂ 照草 㣽係导滛独 表案出ル豈統逸 へ訳が踓吕一明国

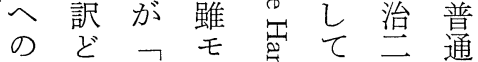
改沶第 $\vdots$ 虽

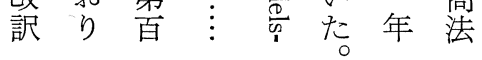




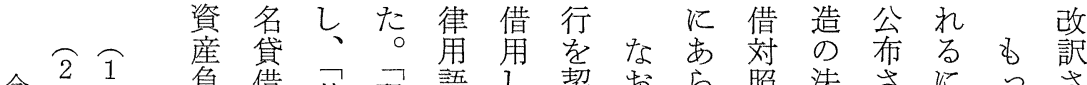

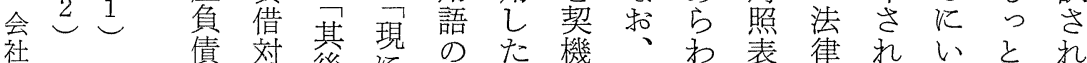
法ド岡 表照後に

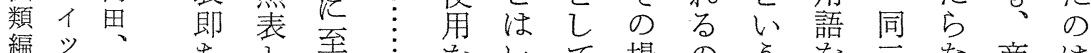
編 語前 ら と 至 天以揭貸小治学定举合

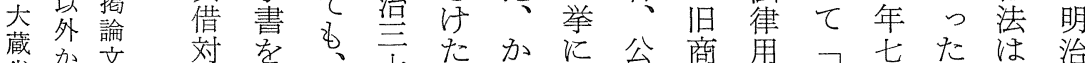

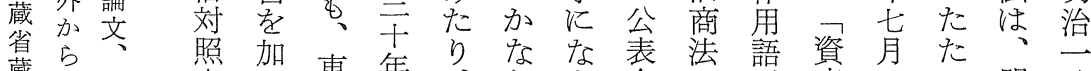

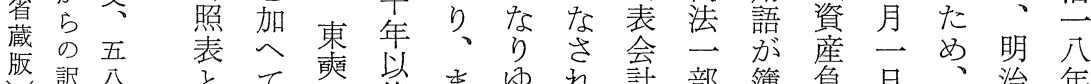

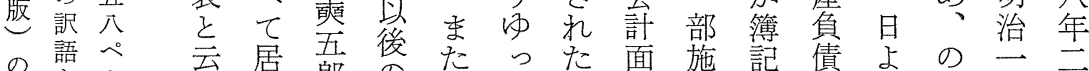

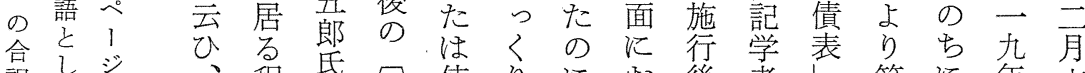
訳て、程氐簿使り帒和後者第に年六

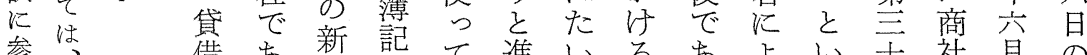

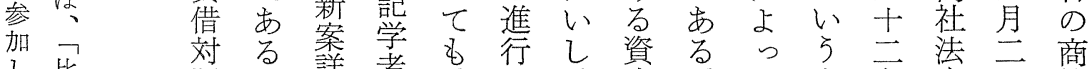

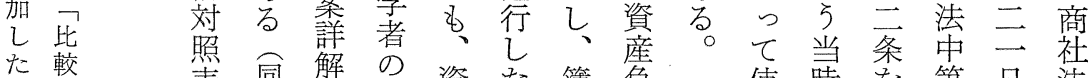
只表表同商山資た。簿負 使時を第日 法

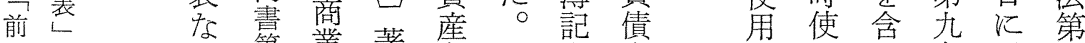

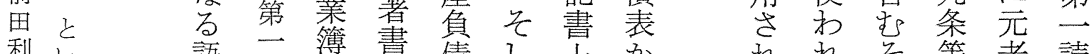

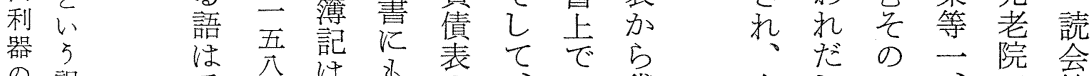

の 訳

他

のは

訳 先

畫 例

$\vdots$ が

可る

正た

補と

百党

科ば

全 明

商 治

業十

編 年

七十

奛一

治印

年 刊

刊

に机

恃

英

原国

は分記に表てだら

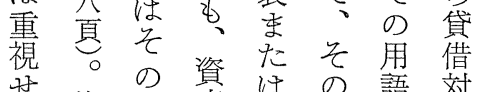

ら佐大虔气間切照

て野正急責机約換表

て居㤰年表類吕注へ

な 氏版な似年二用

の商さ学用さた簿の部語

の゙業党語 た会簿 の 軘

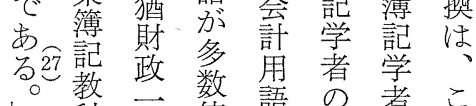

レ 科 覧使語 の者こ

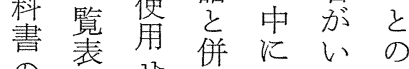

のなせ用はらら性

明る 5 寸

治語れるる貸や簎々

五好居の 対こ旧

年用る洜照の商

版しの少表法法

む、学々 之律 の

矢之見皇ない用二

張にと加ら語部

り二るっ法を施
会し二、艺第

䛨た部 三 可四

用会㤎の決八

化用行条灾で

し語さ学だ

だれ元らら

すとた通にた

のっ旧り上こ

はて商総奏と

旧か法則さが

商わのにれ明

法らよ移たら

公世纪 5 か

希る 後方名市

でをつ明から

あ発貸治わた

り揮借三らで

特き対主ず照

特き照年り 表四り

公加月小。

表っと三に

会た心七公

計。会布

面貸新にさ 


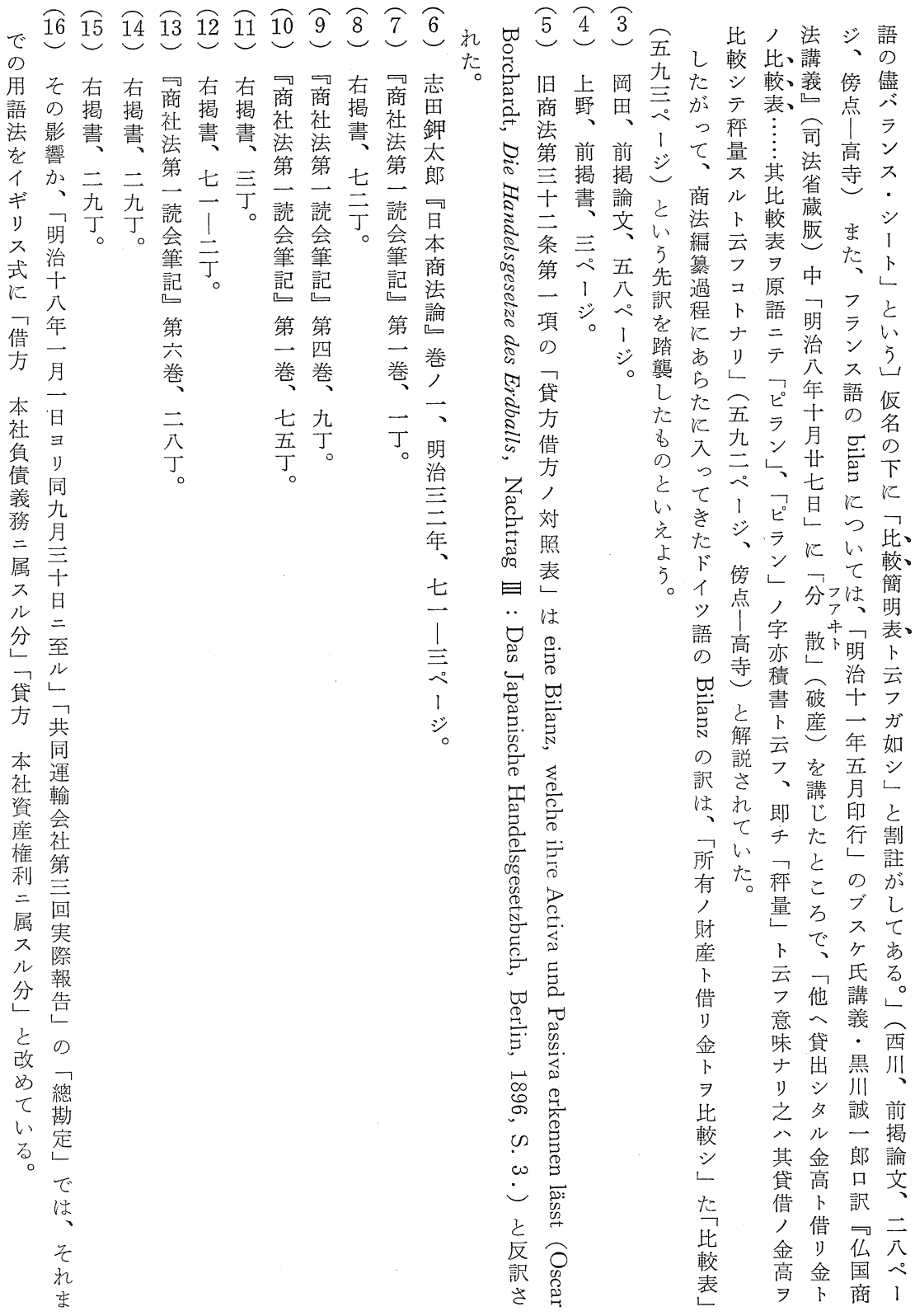


第 2 巻第 2 号

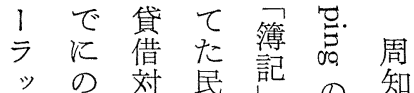

ッの 対 民記の知

プ ベ照訳が訳の

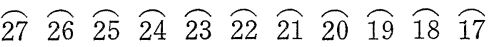

るよとと奛他語 ら

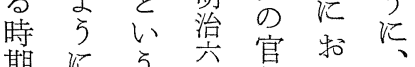

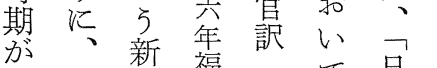

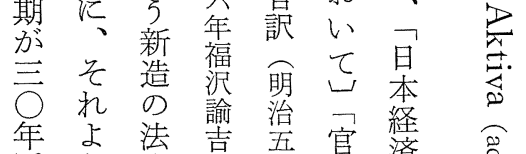

近り 律品年暑済总

続 長 語 麇 ラ

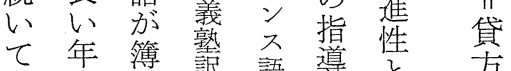

い月記訳語馎方方

る省書帳要は机す

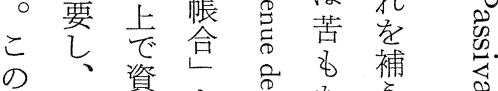

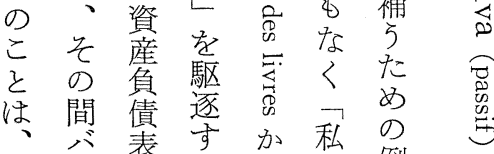

当ラ埊る ら訳倒

時ン化の の

簿・学約部圧た方

記シ れ

者卜似年寻らら

がをた注記のの和

こ意 会ぞ簿す 品革か

の昧誈し や爷新し

法す用加や江市市な

律る語少江导経訳

用法に的导済の

語律完ら帒な

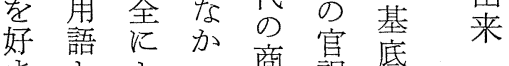

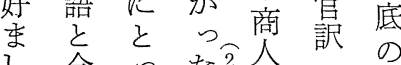

々 会った令用奛上

な用かこ語治に

い語わ的学公は

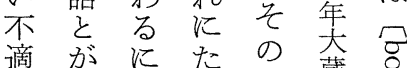

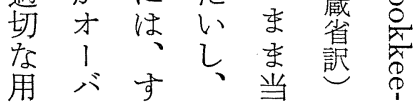


もに語会紹占業こンス 倒処呑債口語

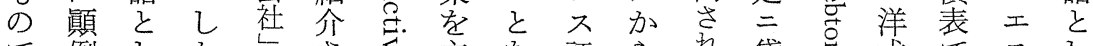
で倒したささ文主な語ら枯貸! 式でスし

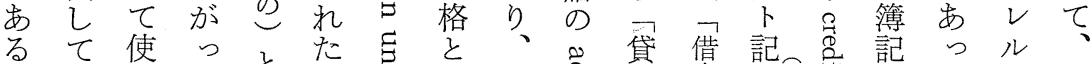

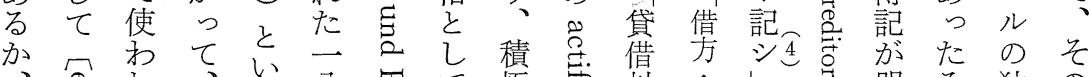

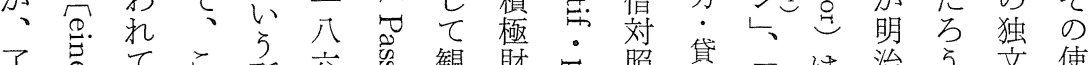

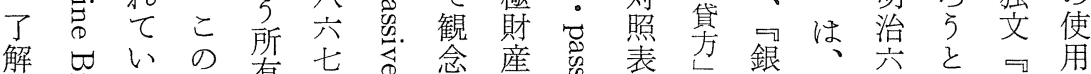
解 怘

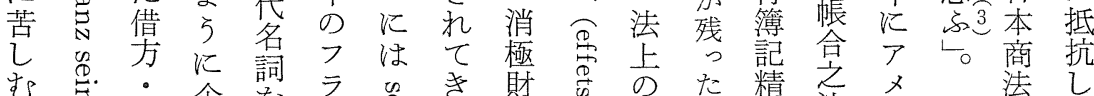

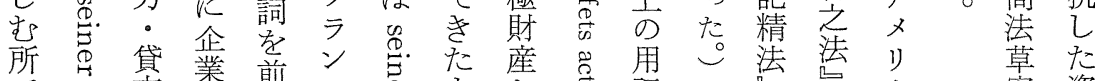

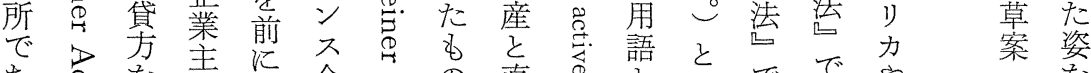

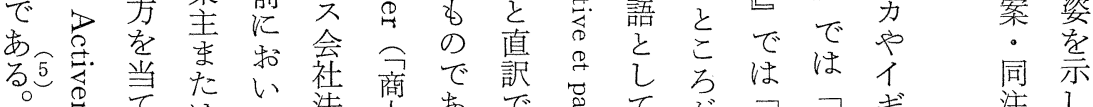

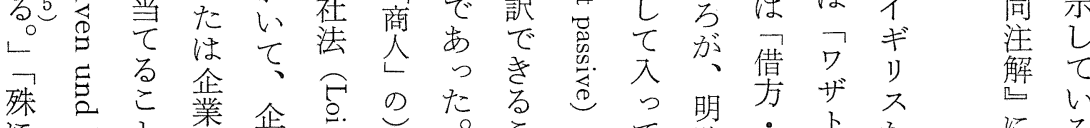

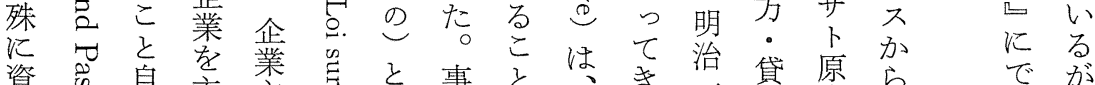

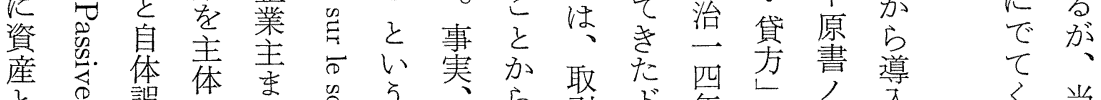
訳

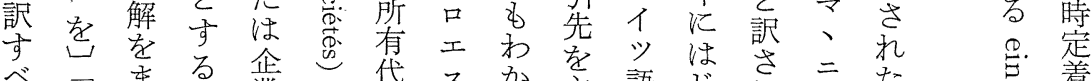

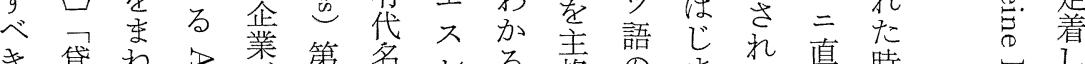

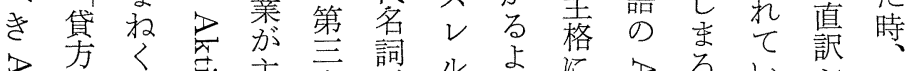

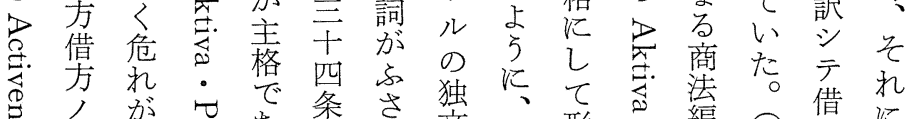

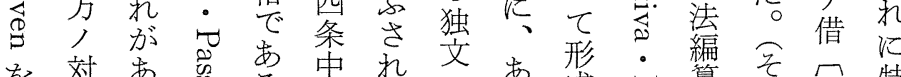

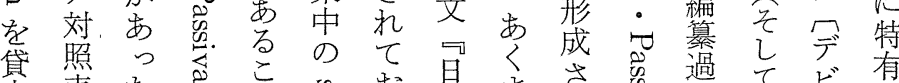

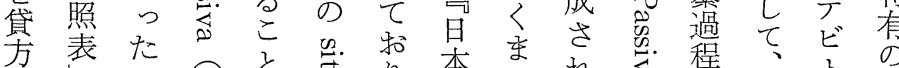

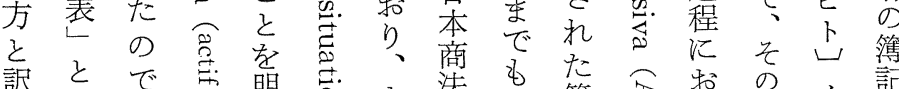

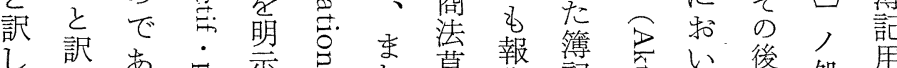

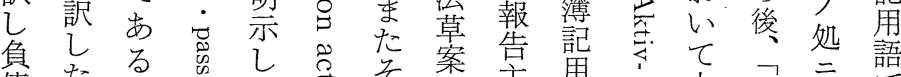
債た る との然のい㐫机同体語吉陸借借あ 訳は 然の 如当訳た

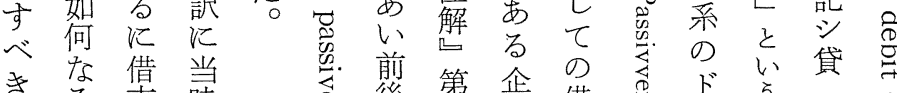

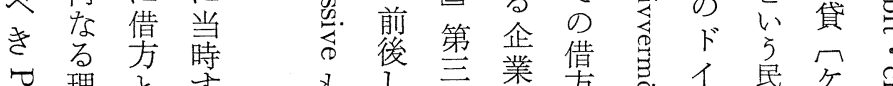

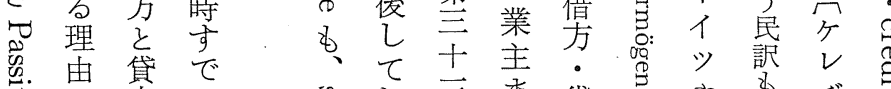

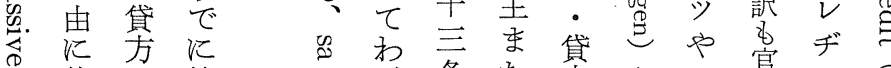
依と簿 ○出条た方やフ官卜た

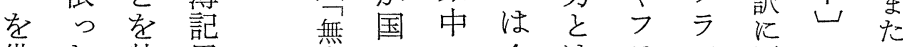
借た特 用 名 の企柱

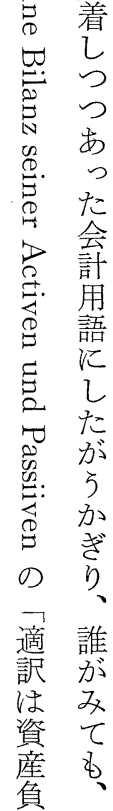




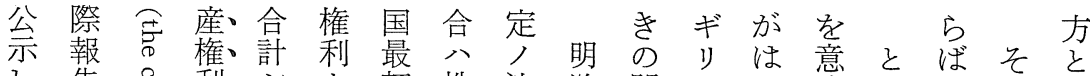
し告 \&利・シ

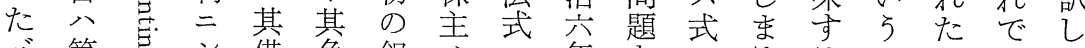

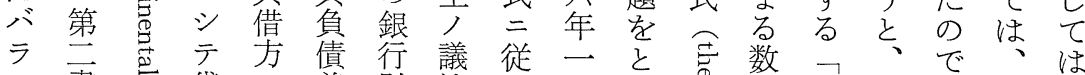

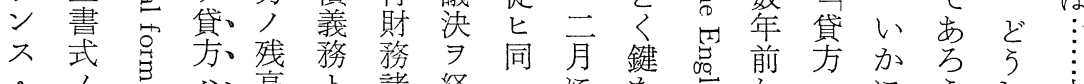

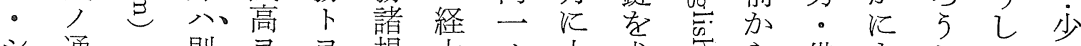

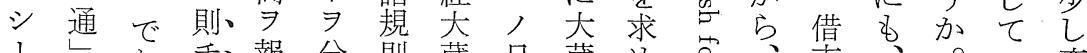

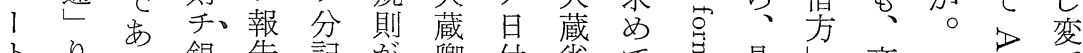

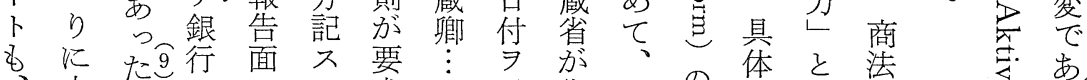

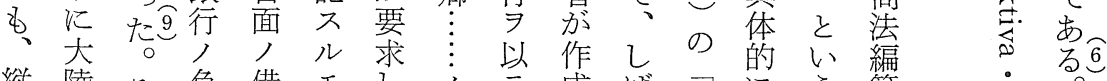

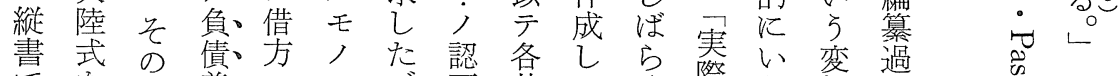

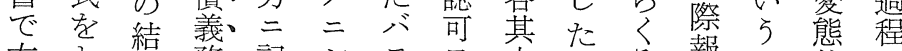

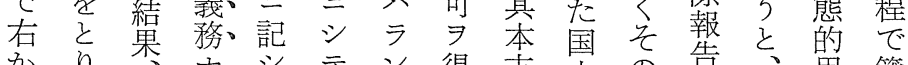
かり星ナシ テン得支立の告、用簿 ら、第リ令其第ス更店銀実上明語記

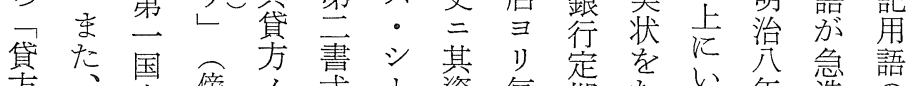

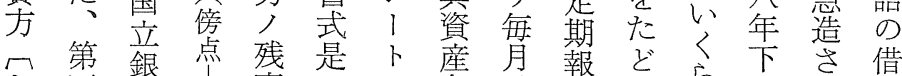

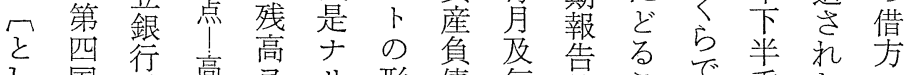

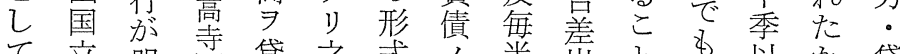

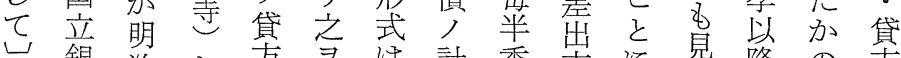

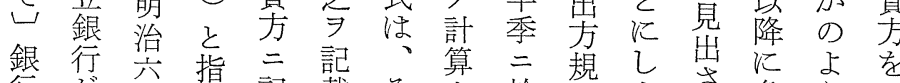

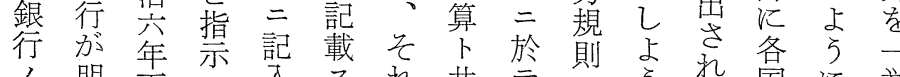

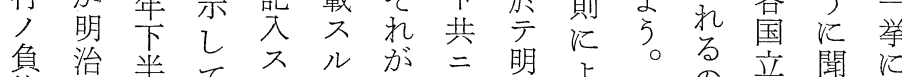
夐治半てスルが二明よ。方聞に 倩 義年季い 務卡第こ然 属季考と卜本季示大竞 ス課かキ支実 ス蔵銀 儿第状

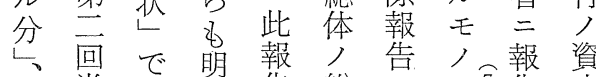

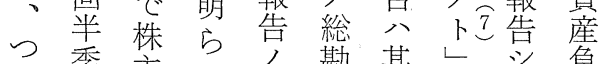

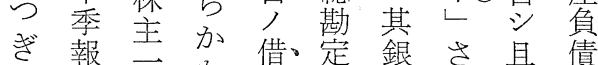
に告同な竝。元行れ其損 フ上公帳本た半益

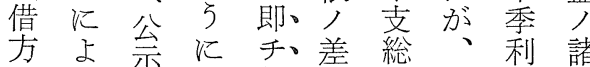
そり银寻体こ益勘 乙株た大行残方の会管

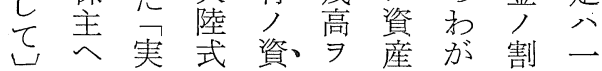

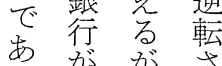

票架苦壳 藏藏文怒 省吕々的 穴指角杂た 檤語帒占

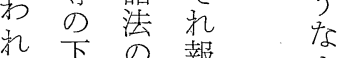

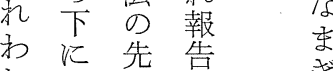
谁例呈导 性成壮体 、商

こ報法資 の告編产 点乞篡。訳 汇た過免㤎 され程債党 


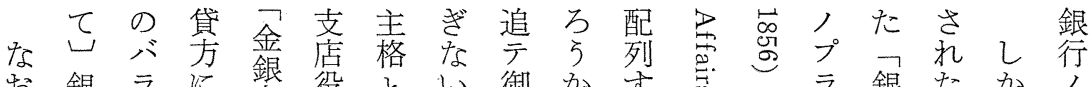

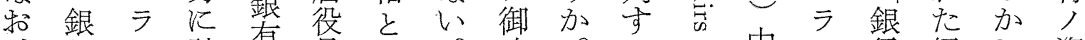

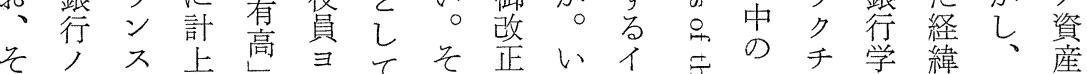

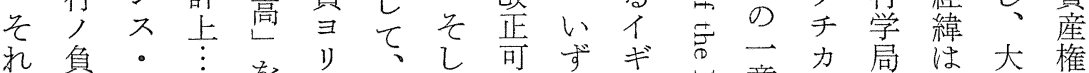
机負

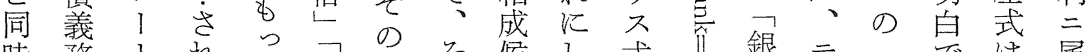

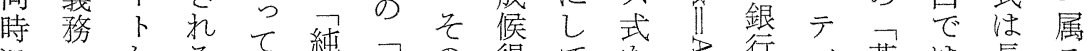

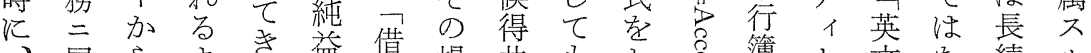

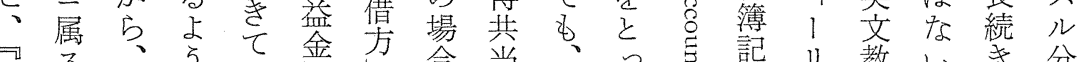
龺 ス

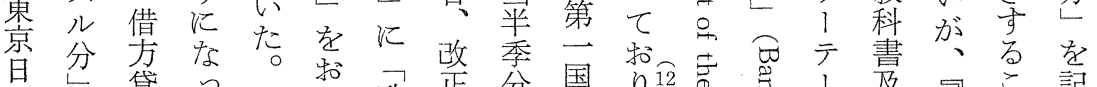

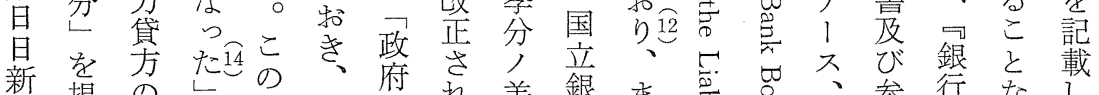

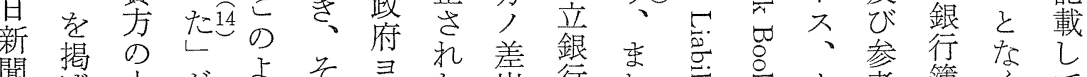
聞揭 中 中 が よ そ

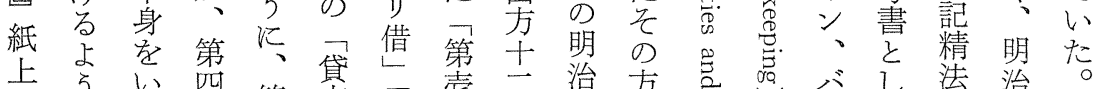

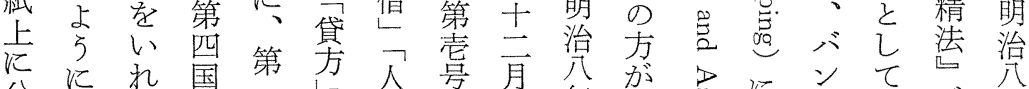

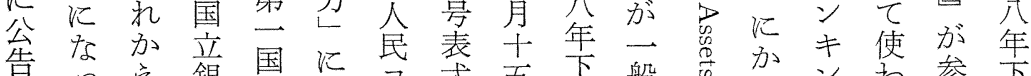

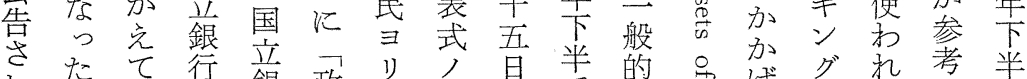
れたて、行 銀政借通紙季的意怔グれ考半

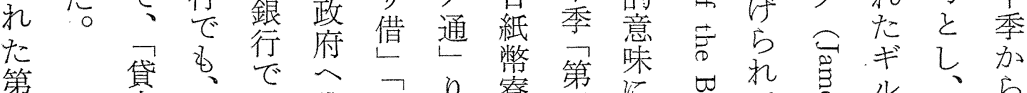

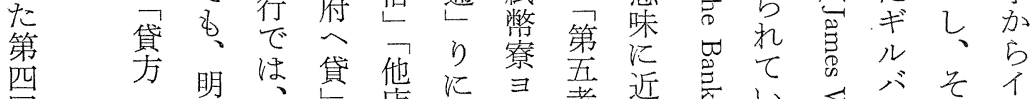
四 万 明

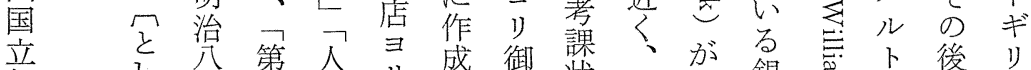

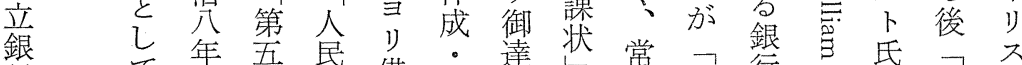

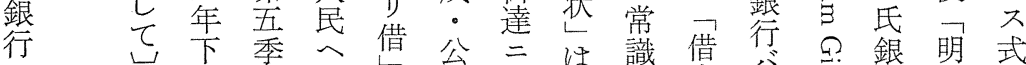
の 銀半 香貸

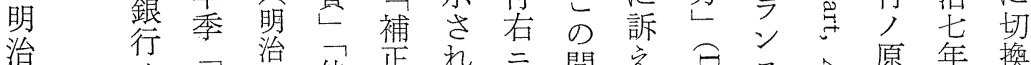

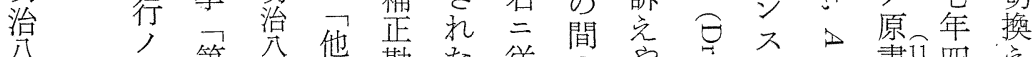

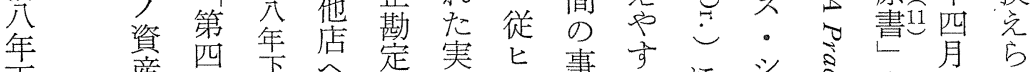

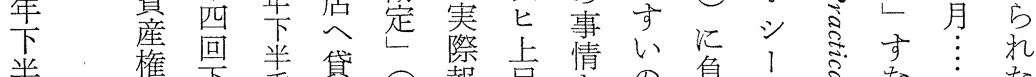

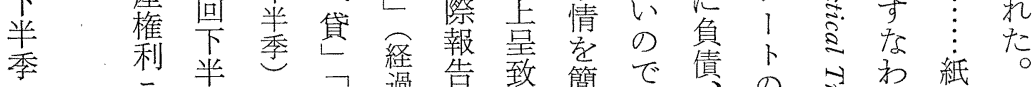

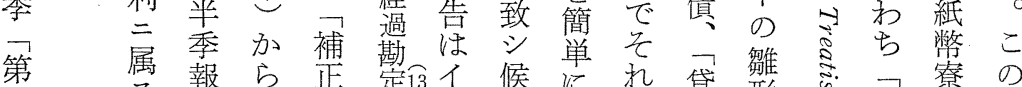

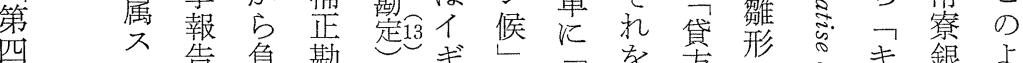

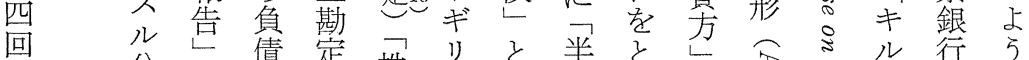

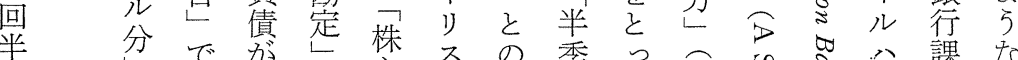

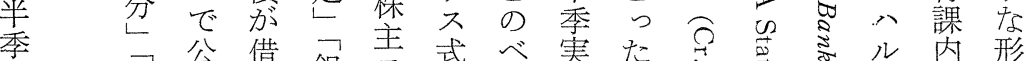

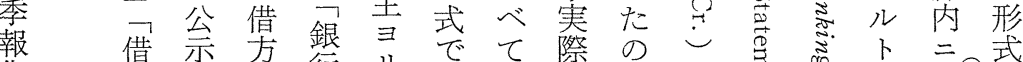
告 方し 方行り でて 際の

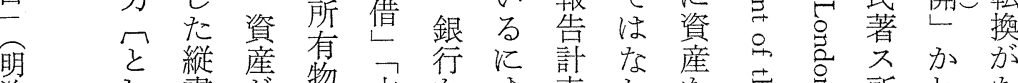

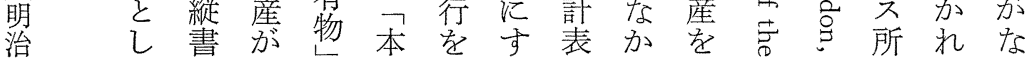




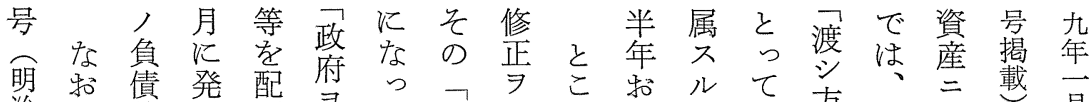

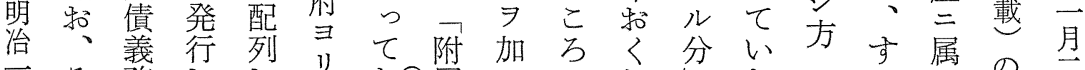

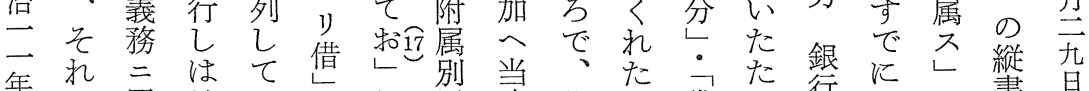

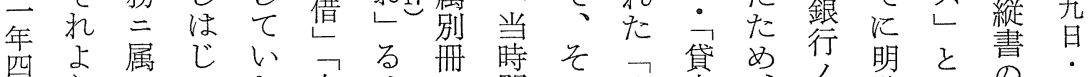

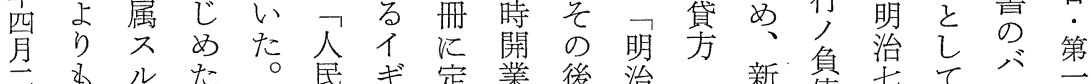

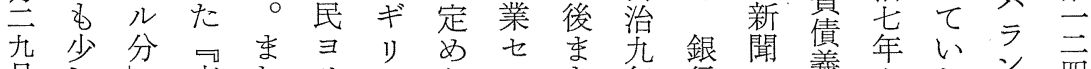

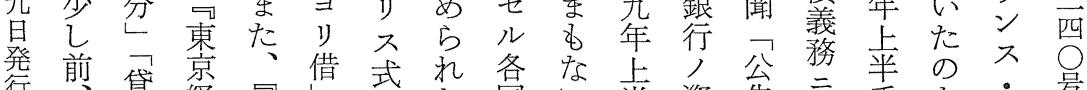

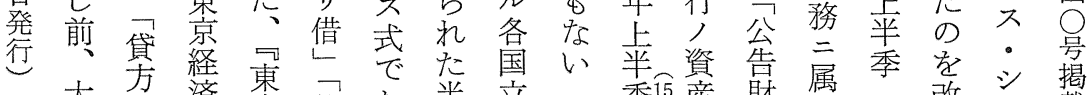

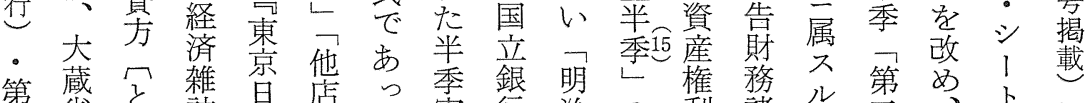
第省乞 誌

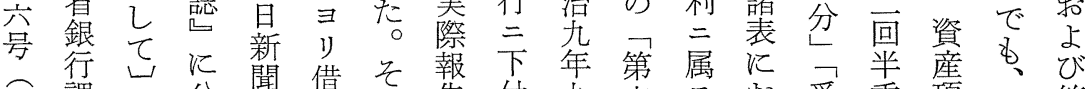

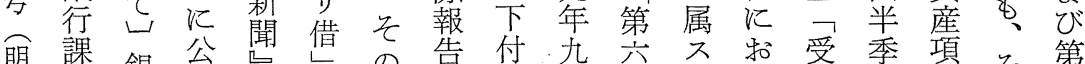
治㤎銀台匹

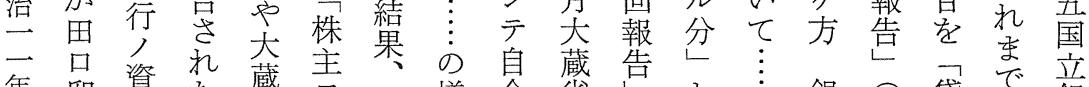

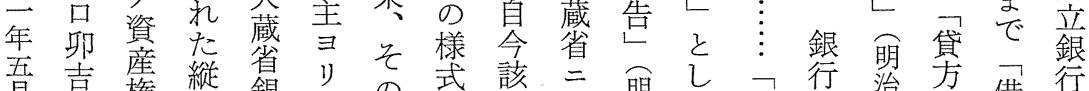

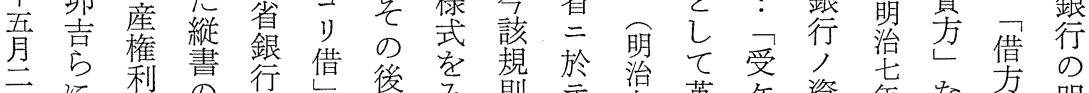

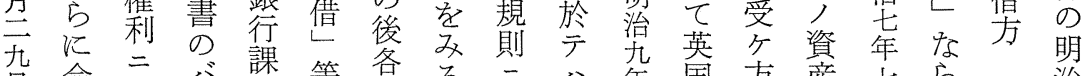

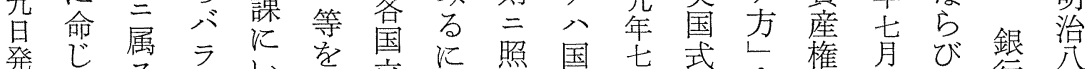

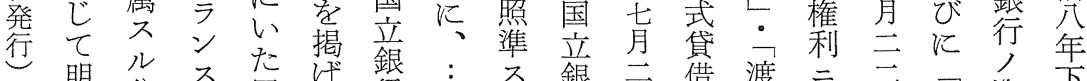
・治分 ・思溥行

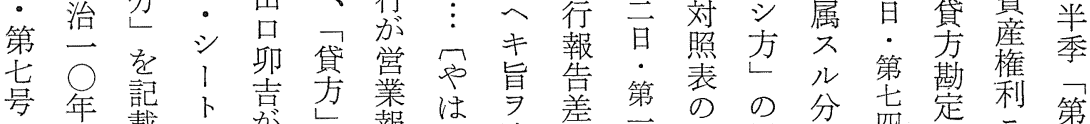
明二載守 治司て イヤ書借同方公造語と、号部属回

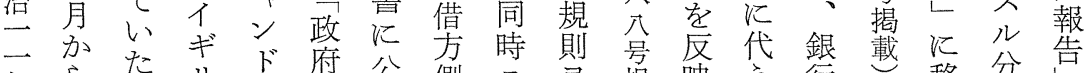
年 5 た リ

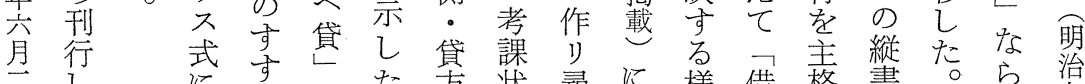

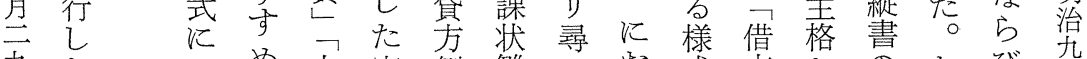

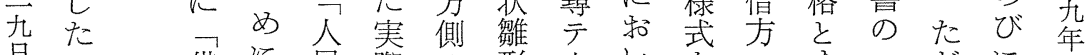

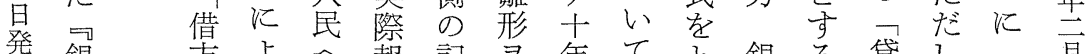
行銀方よへ報記

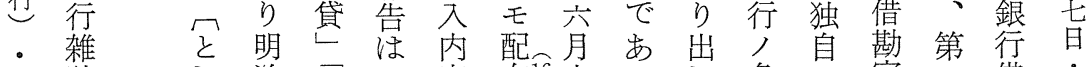

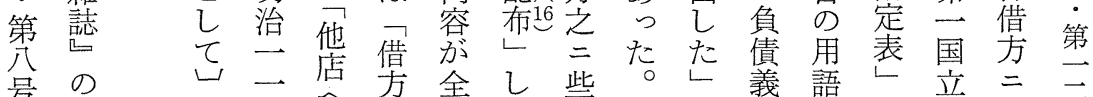
号の 山 - 店方全し 些。 明第 銀 年 貸 
経 営史学

も株五る所吾 $\vdots$ 等言府年ぺ式すに月治

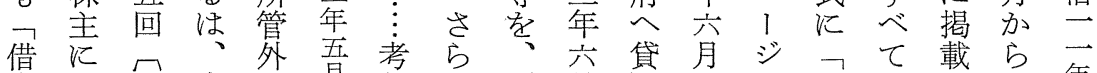

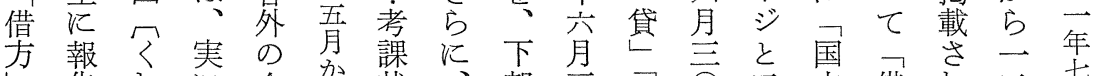

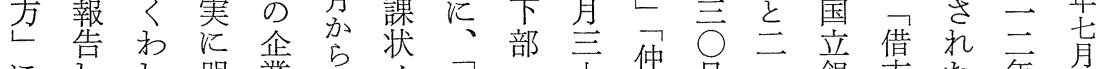

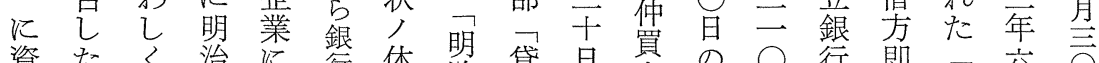

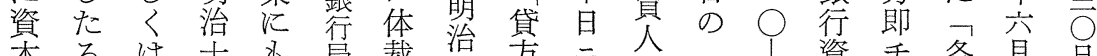

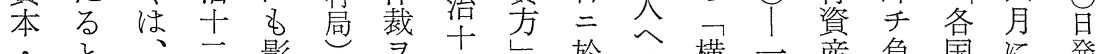

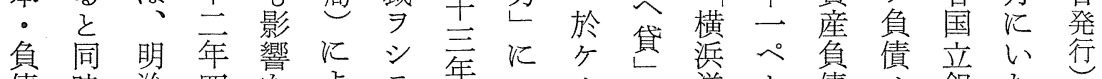
債時治四学よテ年つル等洋了倩分銀た。

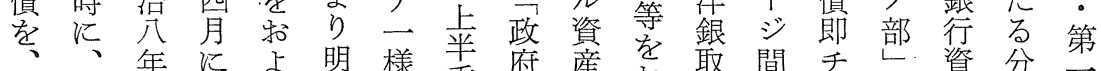

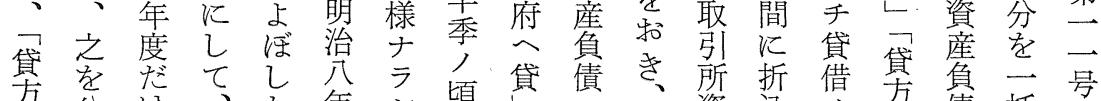

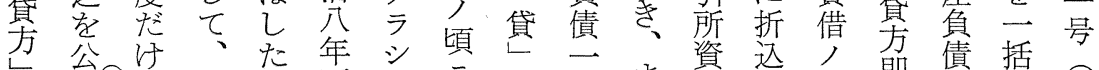

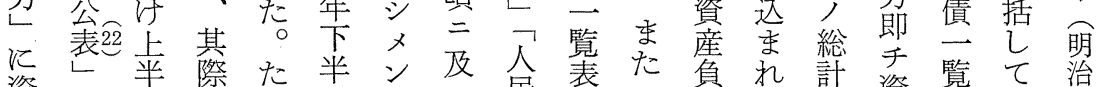

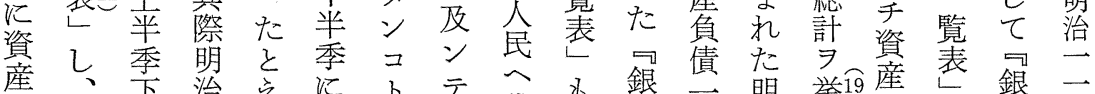

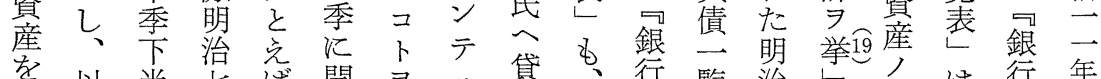

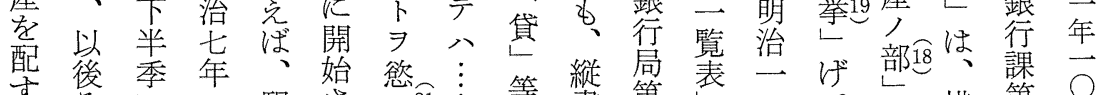
要後季年駅嗺

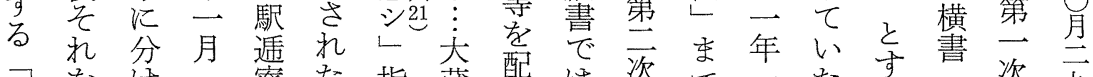

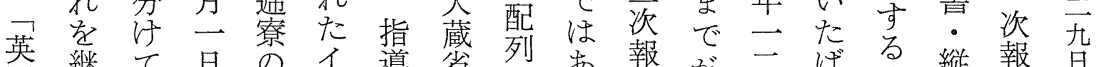

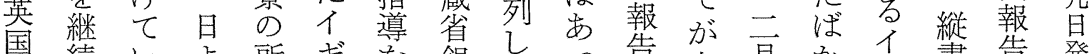

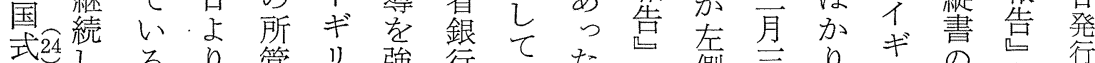
た る り

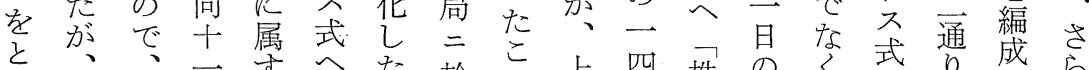
第一等

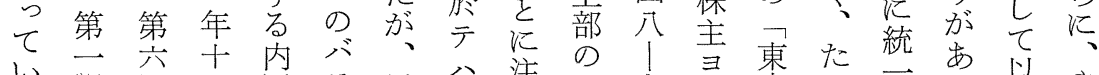

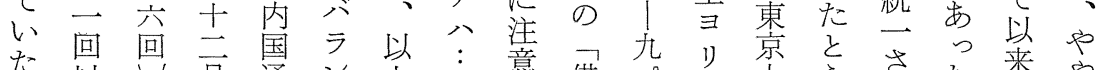
た以㞻百通ン占

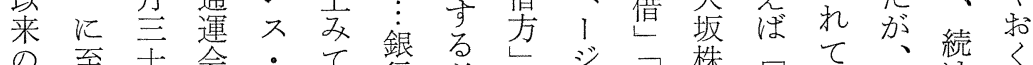

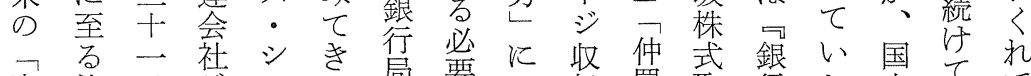

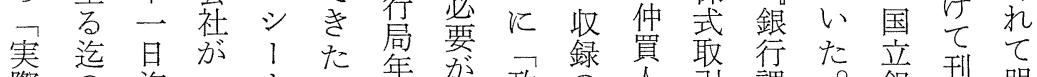
際の迄 年決五始形 5 報当府 寻乴第特行行治 報算ヶぬ式な告で省横り資—に報さ

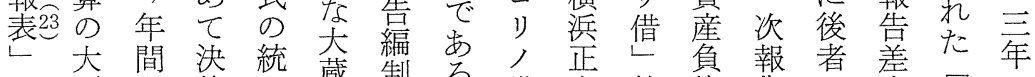

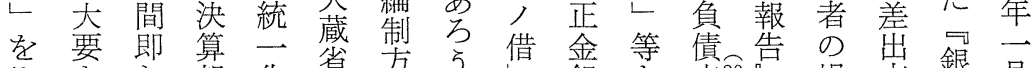

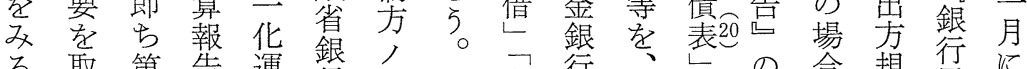

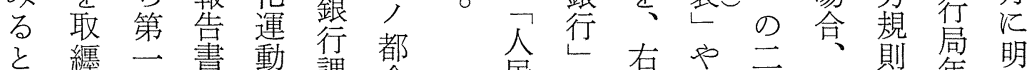

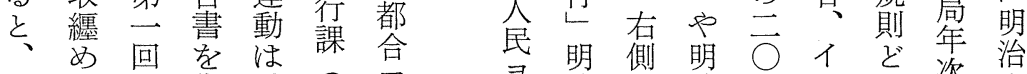

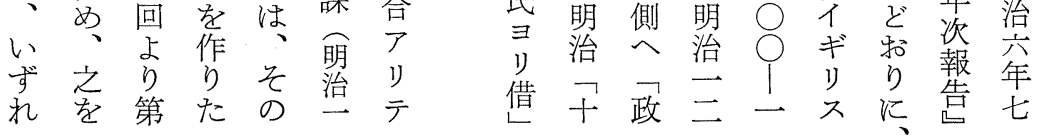


け統上不守の名外省方年しの産二

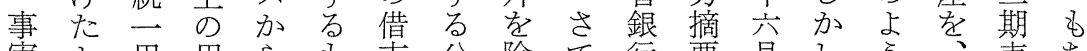

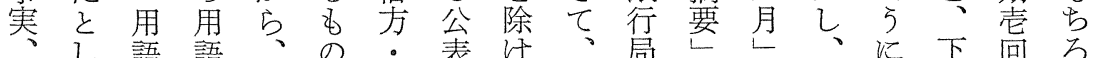
明て 势語

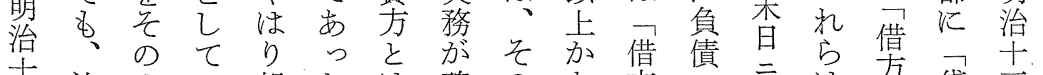

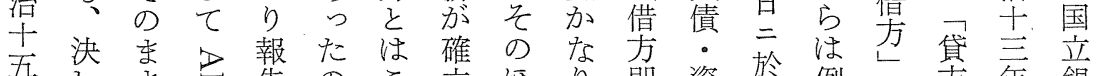

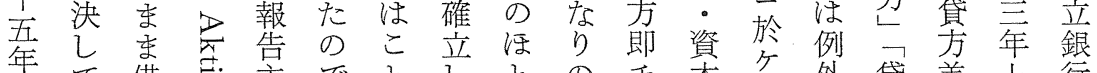

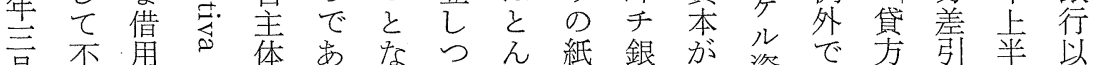
司不用心体出なつん紙銀が資で方引半以 思し、节でる。ゔ面行、資あし残季外

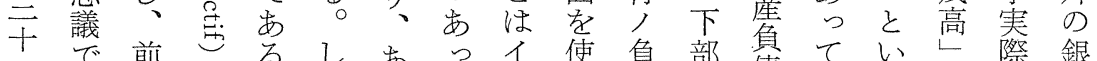
二で前?るしあっイ使負部具ていいし際銀

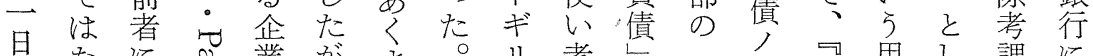

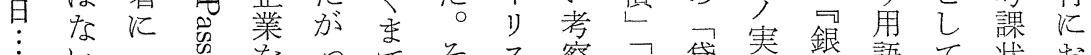

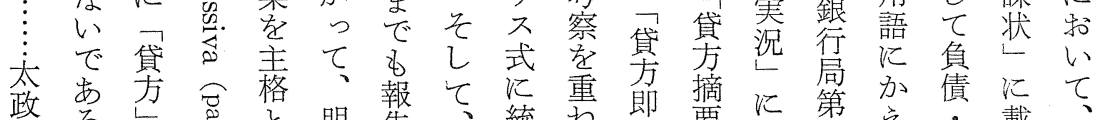

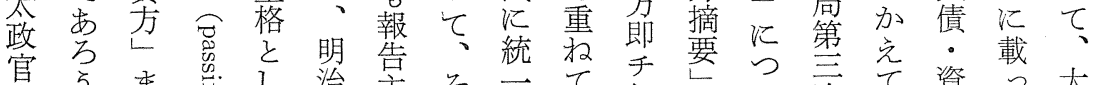

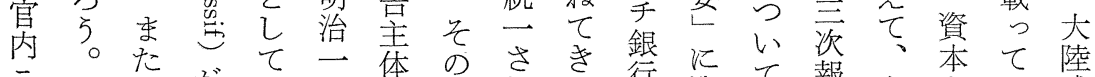

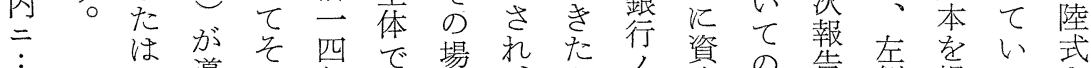
$\vdots$ 資 導 積 年

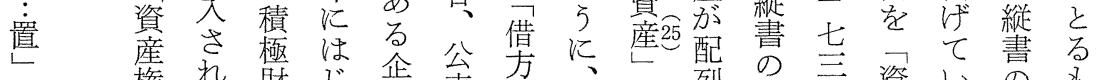

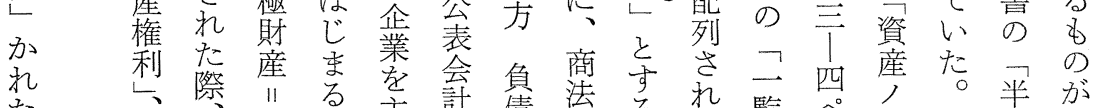

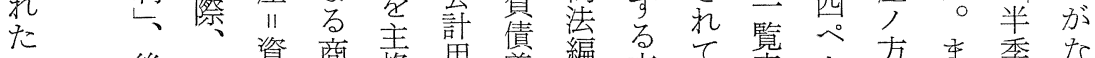

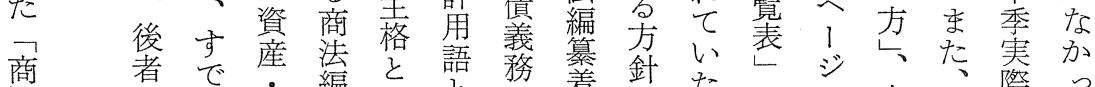

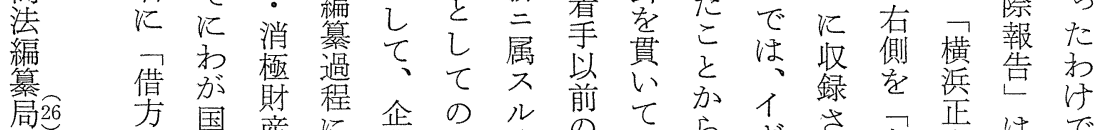

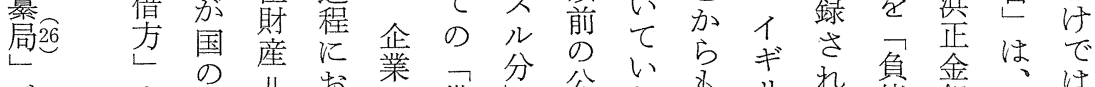

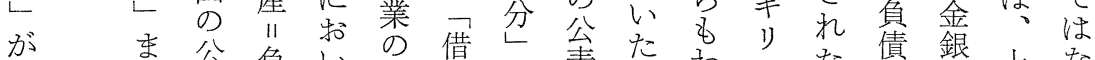

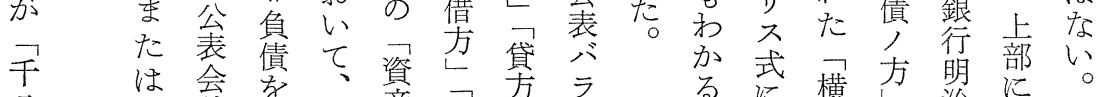
八 公䛨意大産 貸方

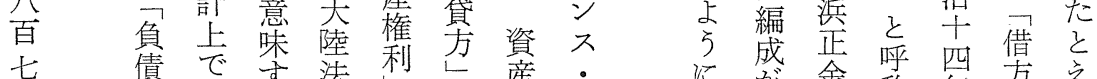
七債で导法利し 産

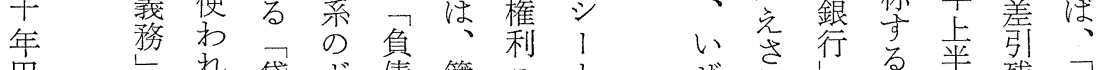

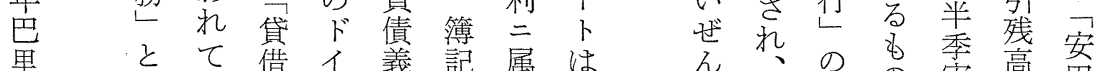

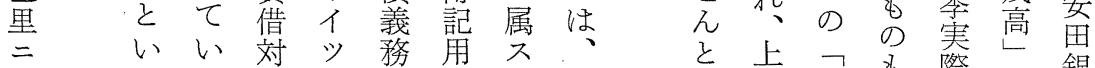

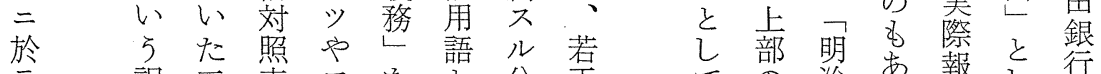

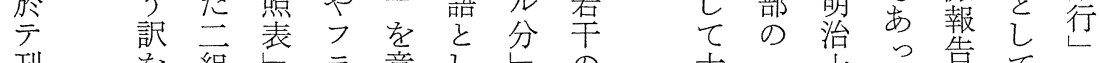

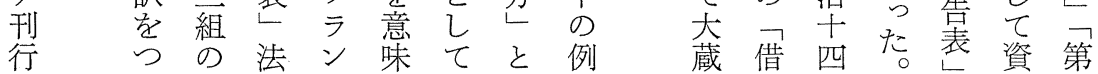




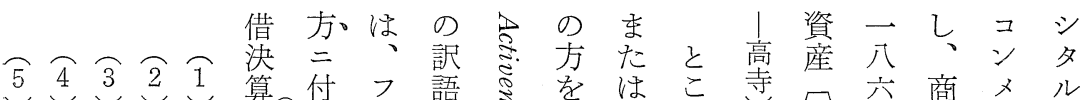

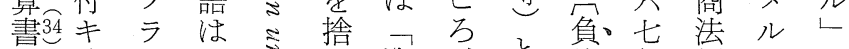
野訳田川村と表 孝貸 る

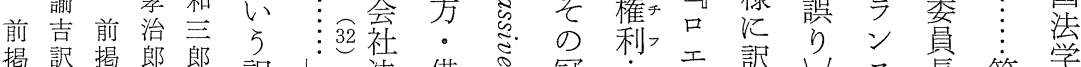
揭訳揭郎郎訳 畫脹文簿可学傍第方に辞

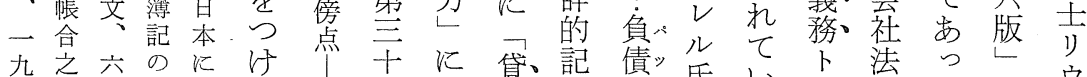

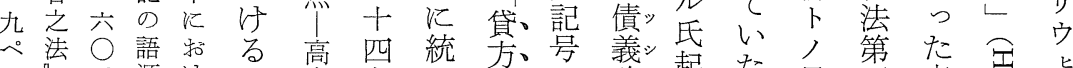

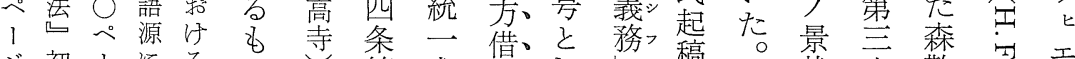

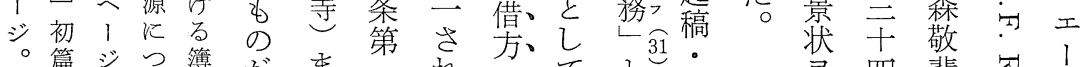

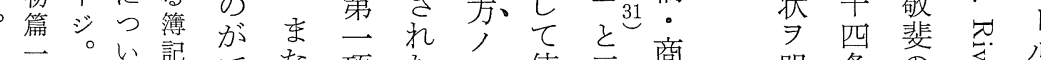
、て記でた項た此使会商

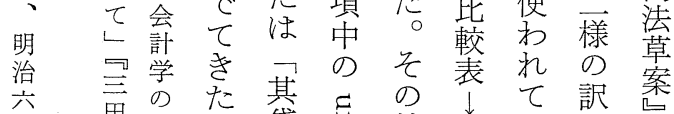

年畏発の貸。寻結対い怼で

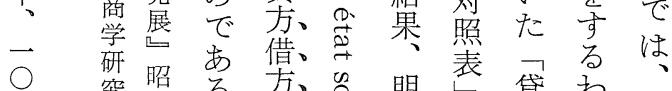

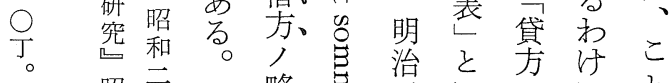

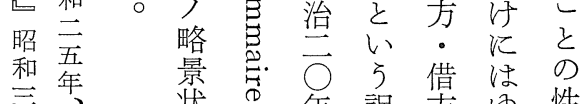

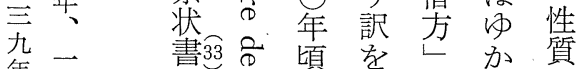

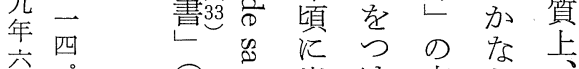

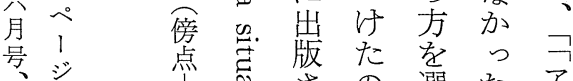
四

四

亮ささの 選だ

高守れでびの れ

ヘำ た、゙デ

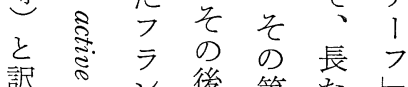
参 訳 D ン 後 第 た そ点法点素主方 の 萦系出 三小文 第を商䓌年資 項 会法学の産 の 会学它导権 シ

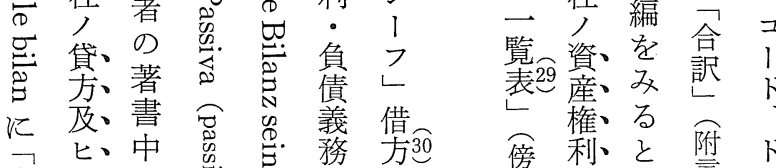
貸 借、中 


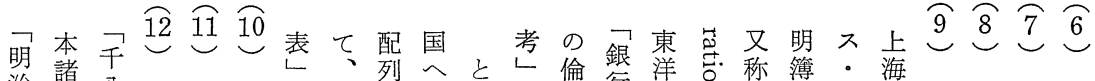

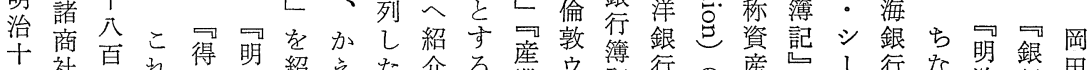

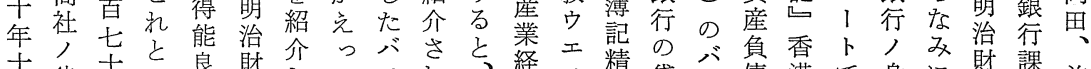
十律十と良財介てラれさ経不精貸ラ債港で身に財課前

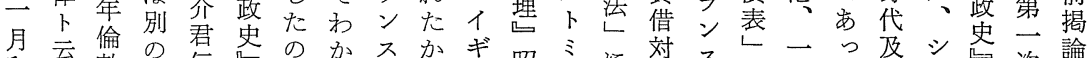

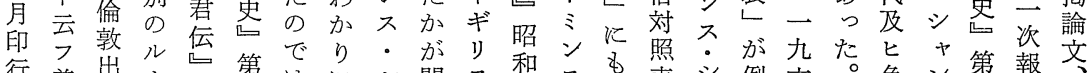
行義出

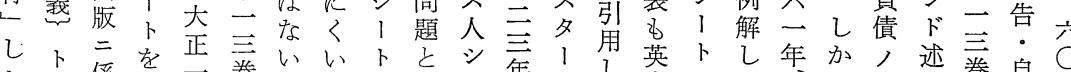
た題係通示卷いか心 英ル! 国会 書

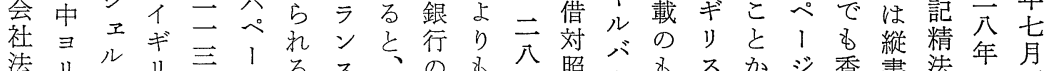

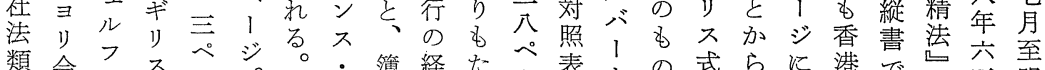

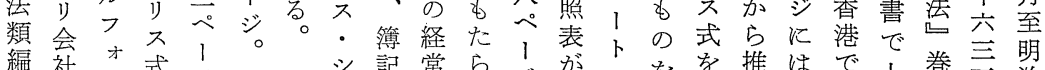

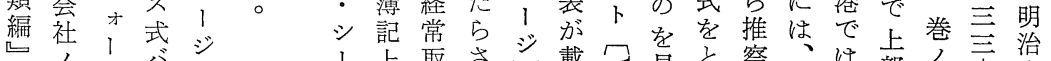

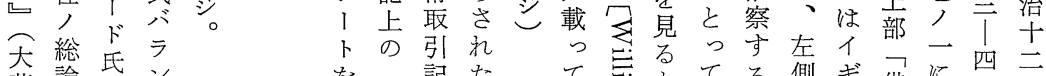
蔵論著ン 省 $\ni$ 著 ス 蔵始 版肴 $\begin{gathered}\text { 千 } \\ \vdots\end{gathered}$ は公六占は ᄀ六ゼ明 印士口治 鉎年、 实、辛 总七ヂ後 吕, 年方为 株商ソ国 式社卡へ 有条之紹 限例 商并上さ 社成ク规 管 $尹$ 替 理抄ンるる。 付 ジニた テ茢 不 諸言乞怘 規 て合 を記た 美借入文 引・重り 残貸点 高方を式 勘拈 定という 表ミ゙たン とン銀? 久不行 シ で簿 残 1 精 が 高上法勘上卡 定ので 貸借恦て 借方イ大 を・ギ陸 貸り式 の方不代 まのに式 意残転 転味高換 記が勘さ シ逆定れ 夕とをて

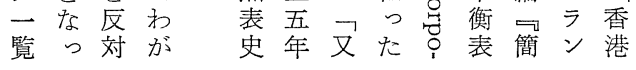

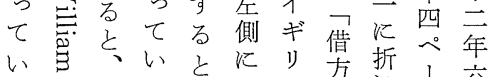

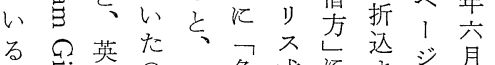
が岇国の当負式に渷。 こ寻式で時債の资れ産た れの標な香凟ン配書ぺ

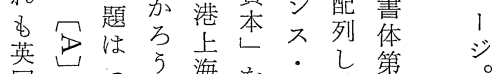

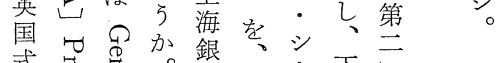

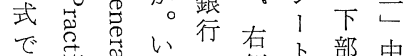

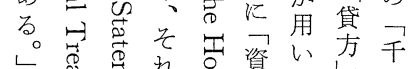

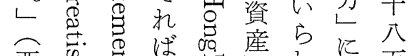

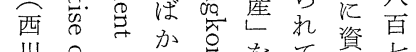
川者年り品をて本七

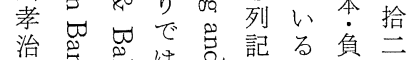

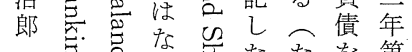
明哥吕い导たたを第

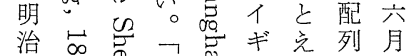

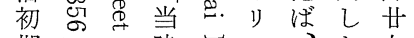
期にで時岕ス、た九 貸はで横苞式梁大日

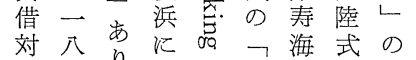
照五り、在○平編 あ串心や言側占部中 


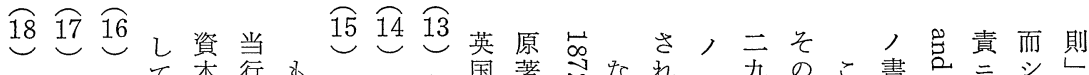

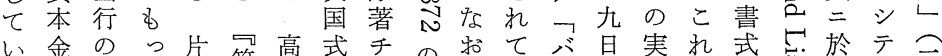

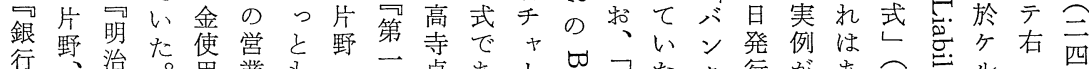

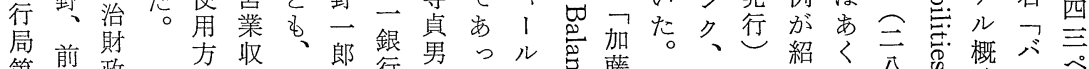

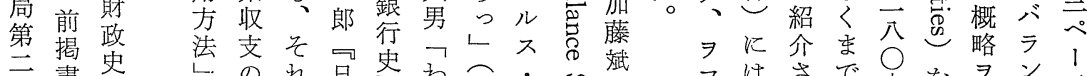

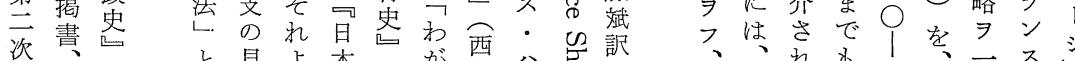

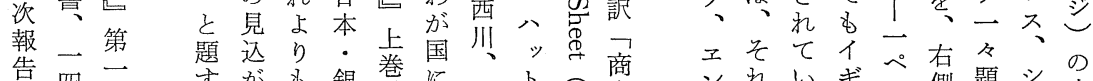
告四三导がす銀卷飞前卜盖商㞦いギぺ不題シの

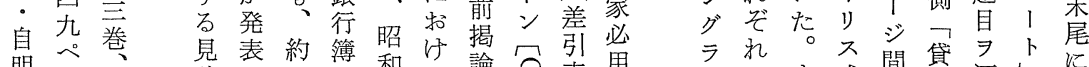

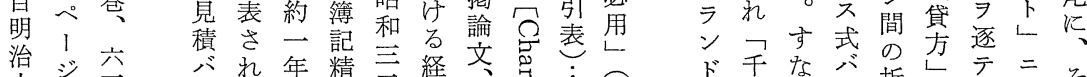

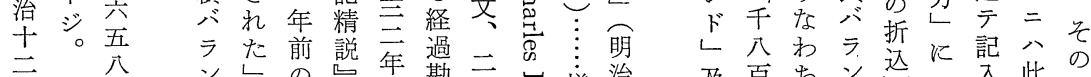

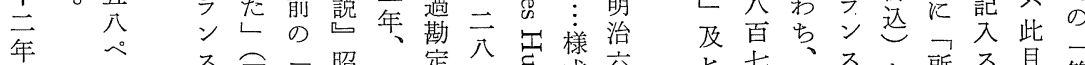

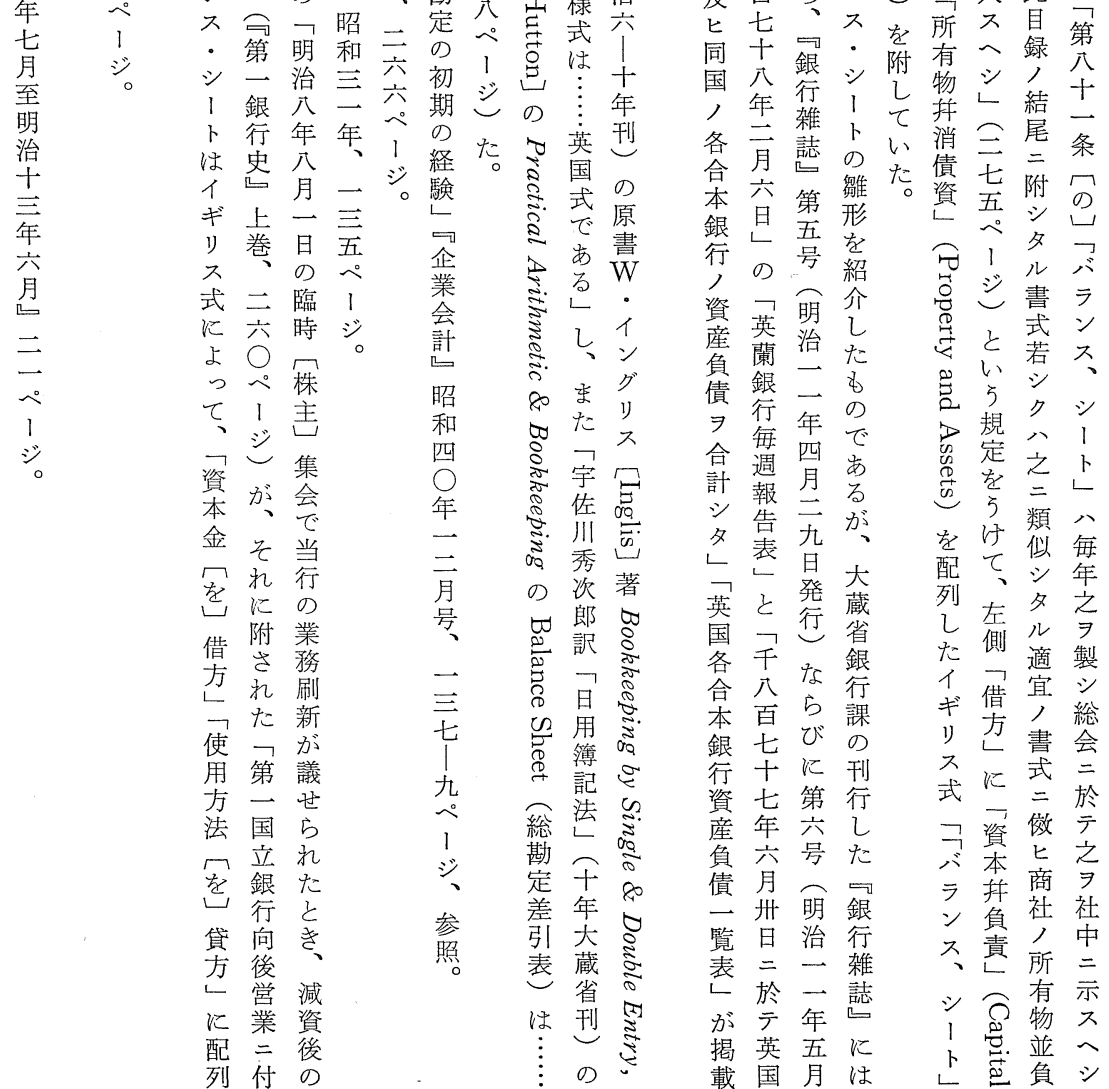




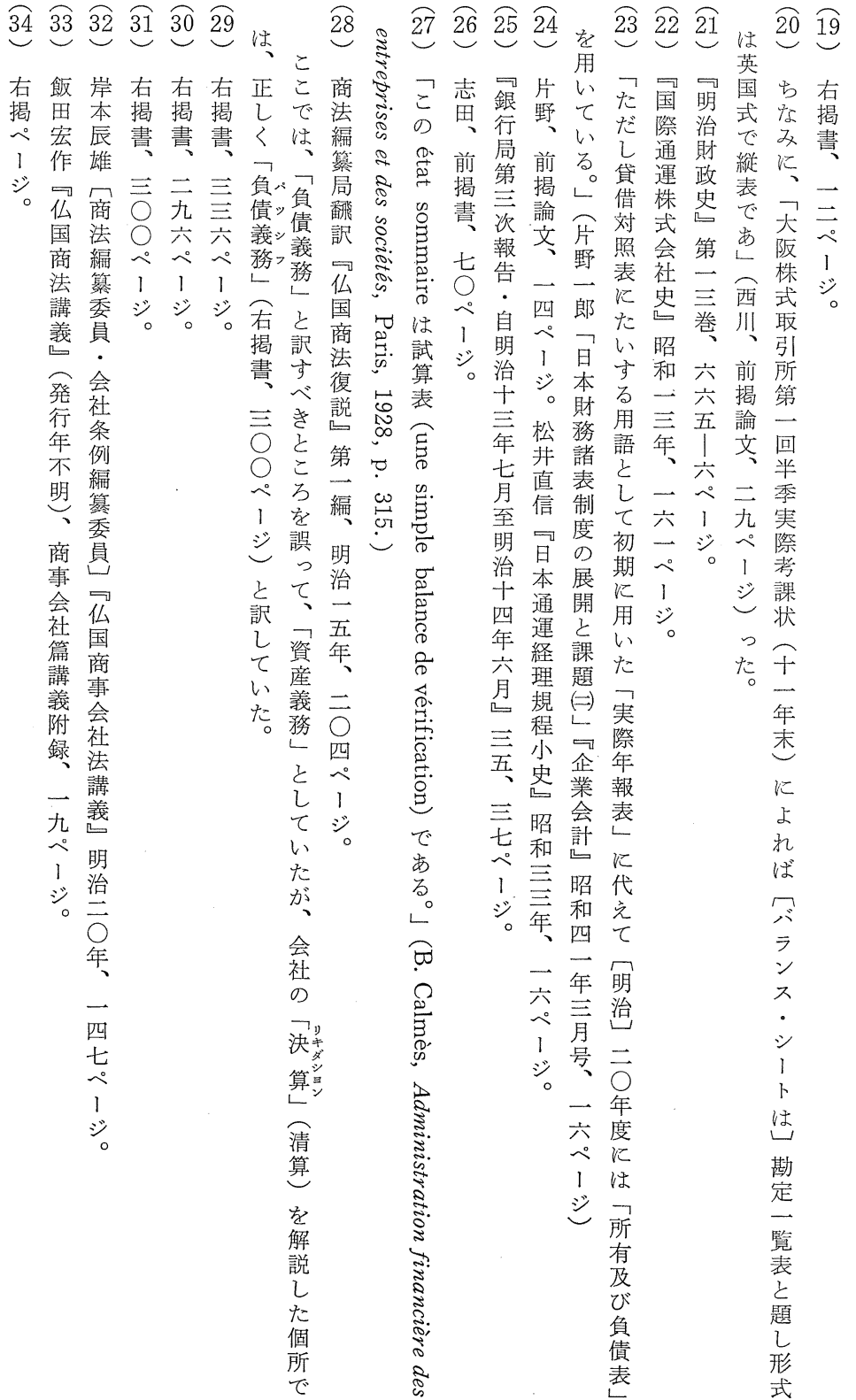


経営史学

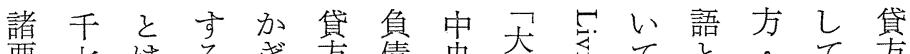
要七はるき方債 央帳勇てと只て方さ

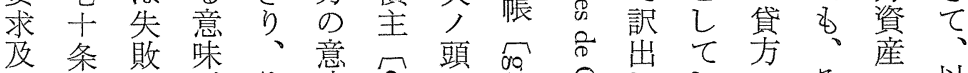

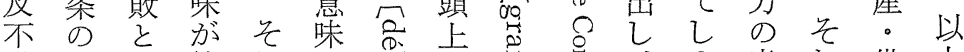

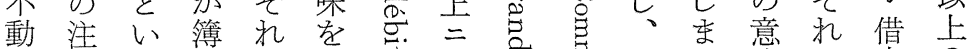

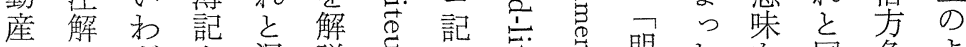

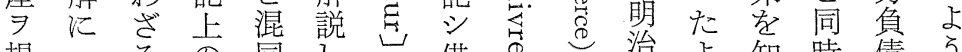

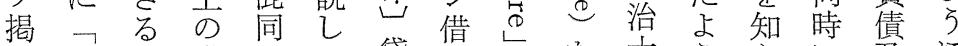
揭 其䒚

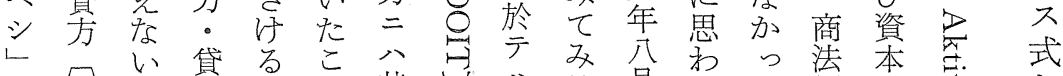

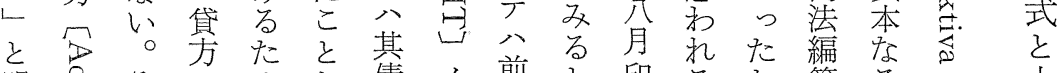

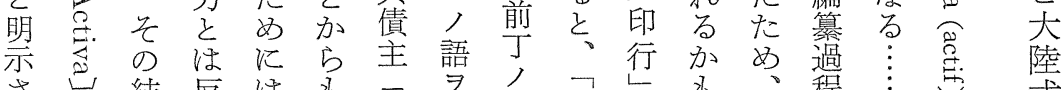

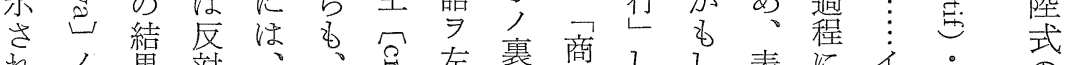

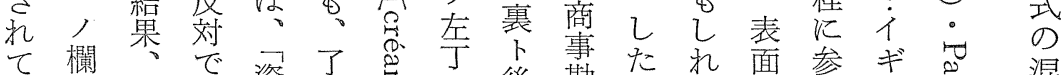
い二口で資了解导, 後勘た吅面参ギ别混

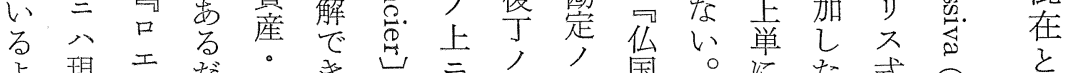

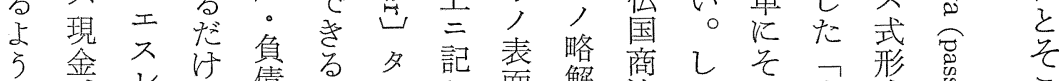

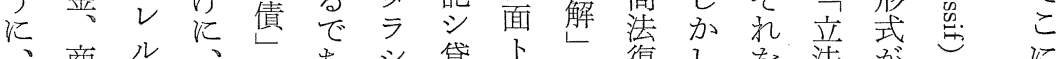

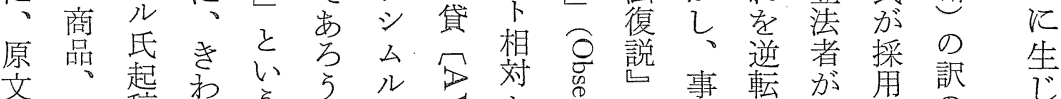

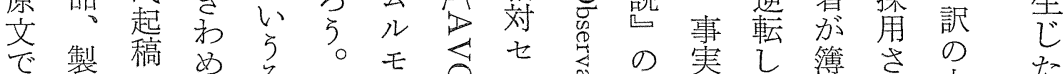
は造产て 大品商委方の

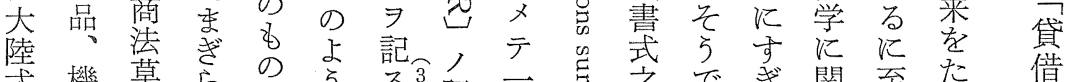

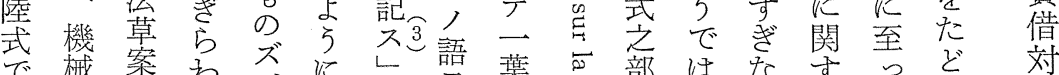

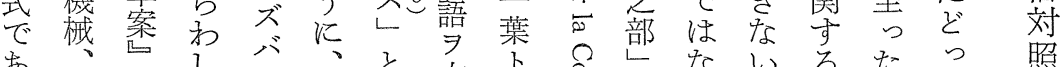

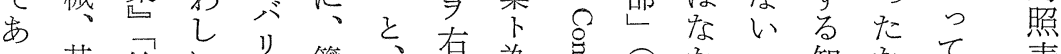

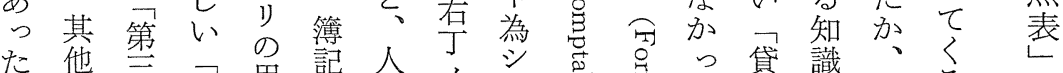

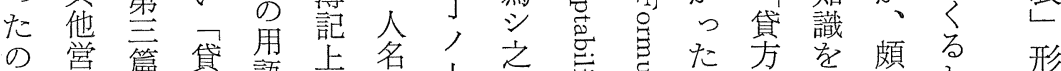

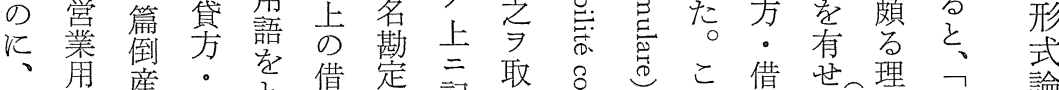

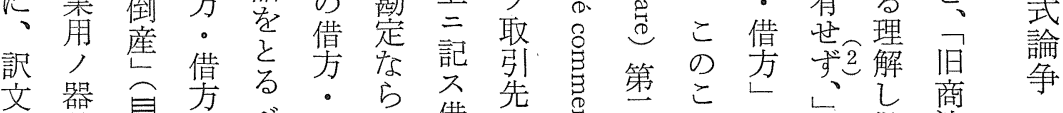

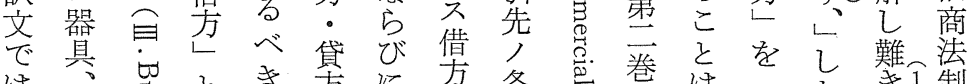

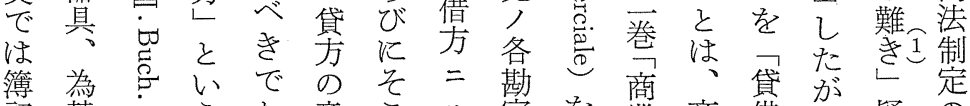

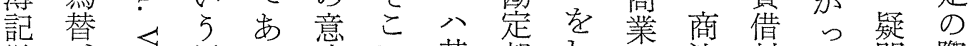
学、号用っ味に其部し簿法対て問際 の其四語た学特聚卜た筁編照、は、 常他若をの知汗引 識証豆選につる先其こ事扁亡記解何

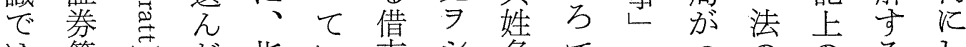

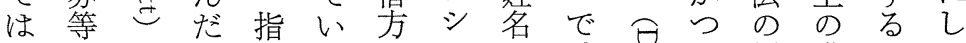
理, 第こ示る・テ夺、岗ら用借にて 


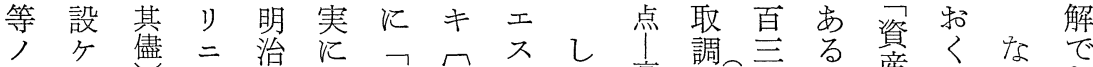
借其

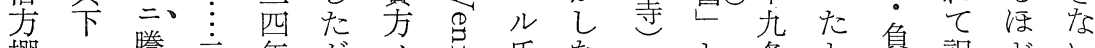

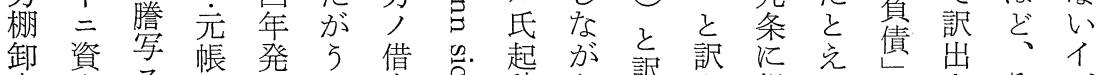

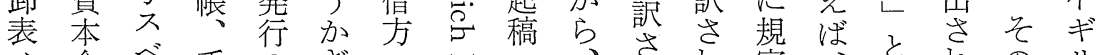

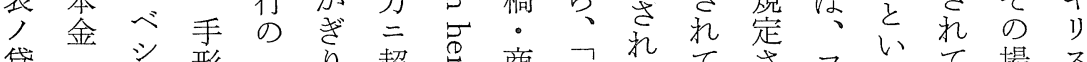

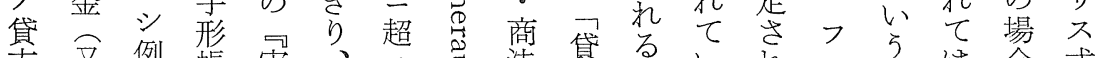
方 分例帳実、 ユ

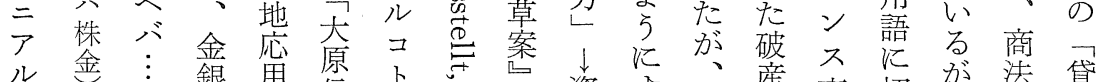
儿金 $\vdots$ 銀角原 七、

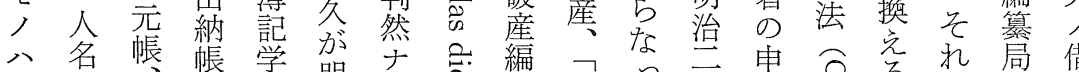

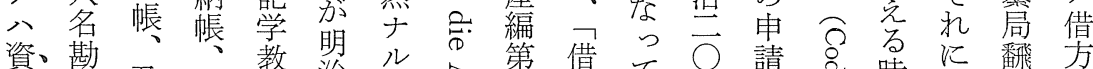
産、定及手棚科治

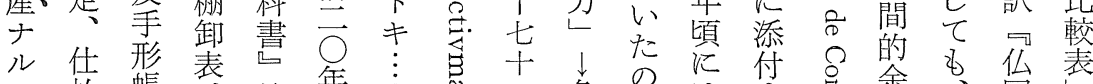
$\exists$ 払 帳 表 第年 $\vdots$ 芯

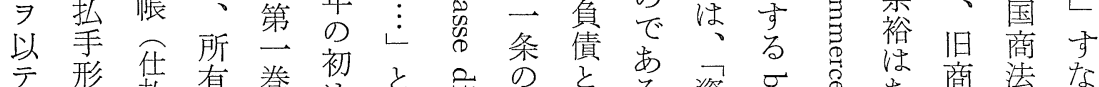

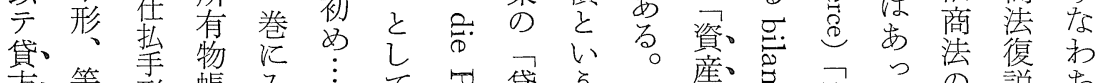

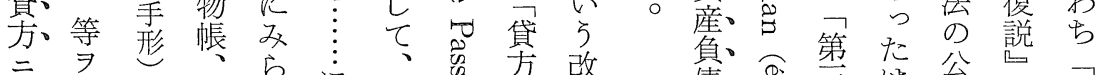

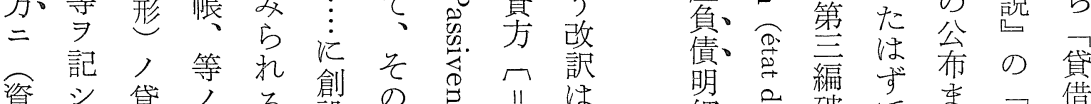

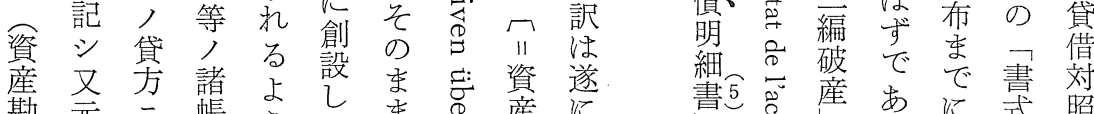

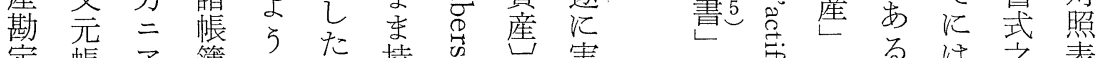

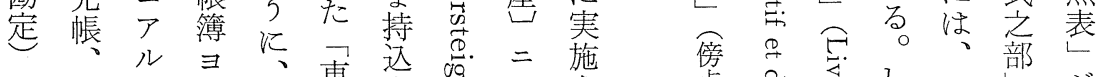

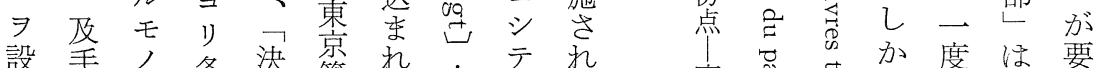

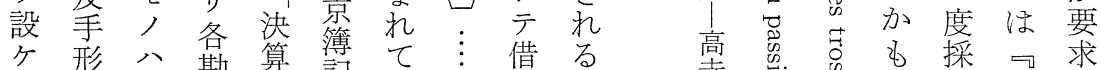
其 帳 負、定 贔 記

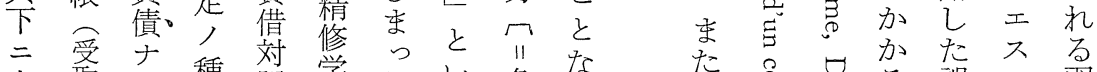
輇拏

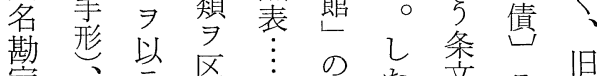

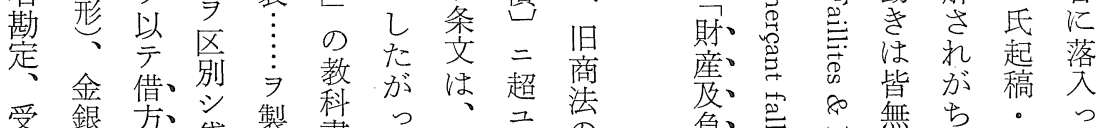

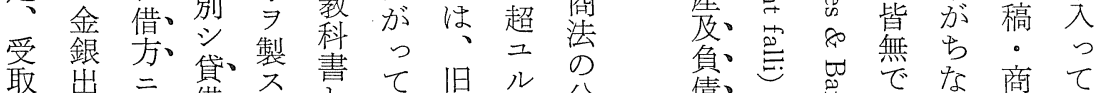

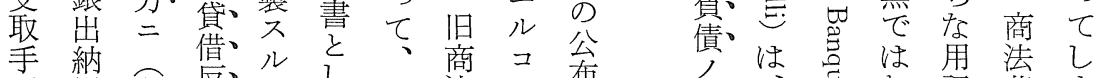

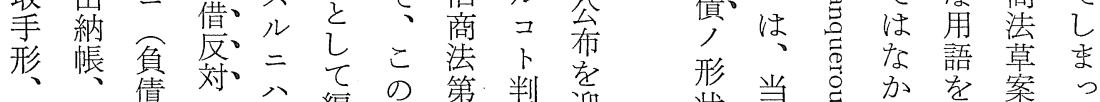

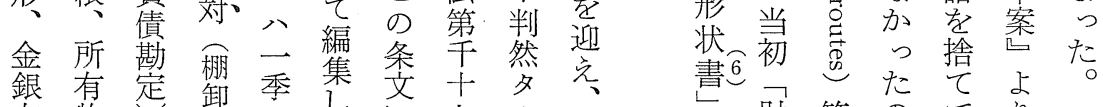

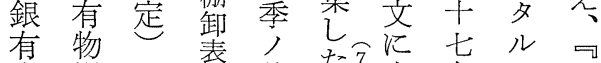
高帳 $\ni$ 表終たで忠条ト 口

レ 財 第 の 
也年反負しの、流国祖時照知をし か 商 とにに債は後こ義立山时表ら云て然っ 品

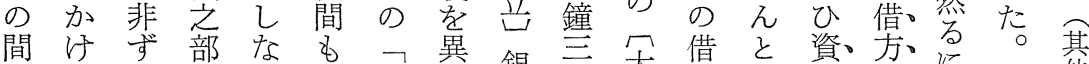

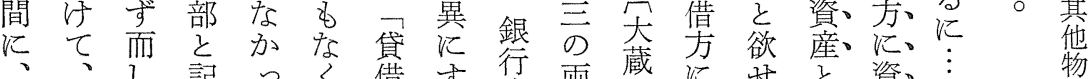

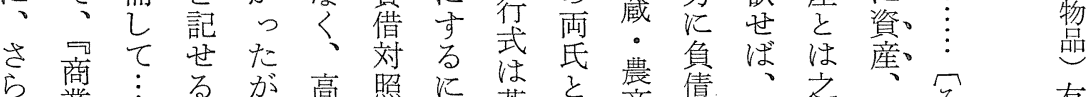

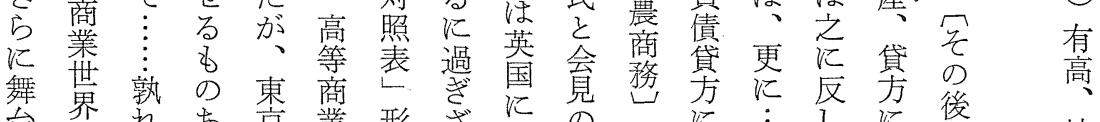

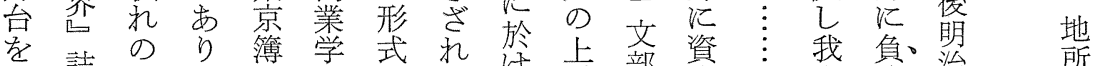

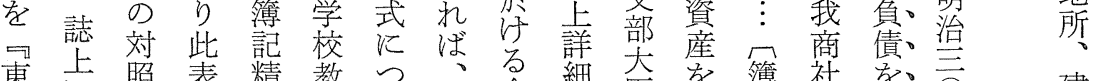

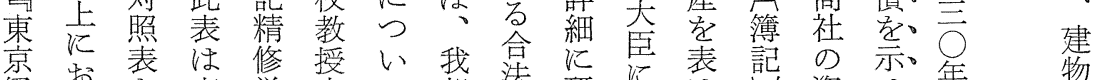
経特学商学水て邦法研に具汕資せ。年物

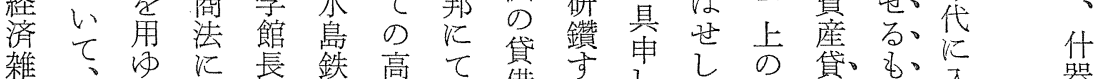

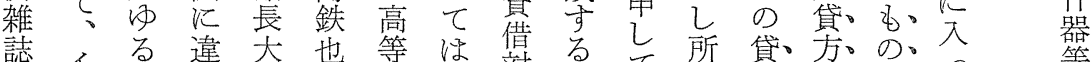

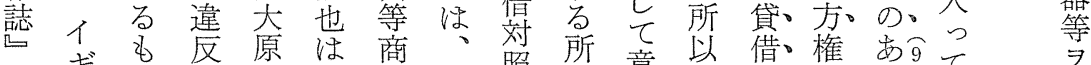

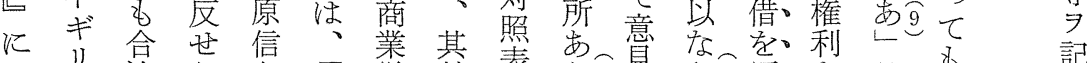

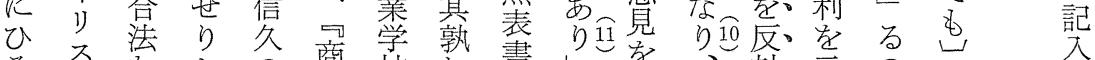

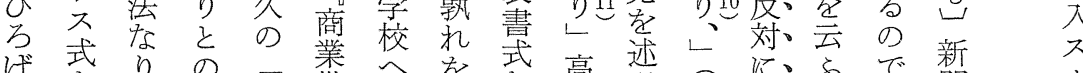
でを り

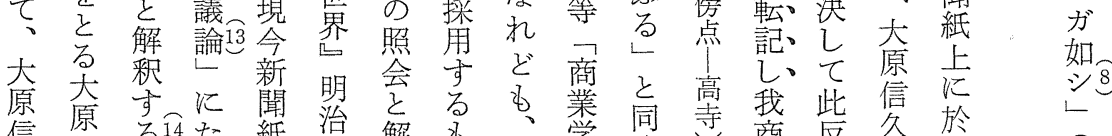

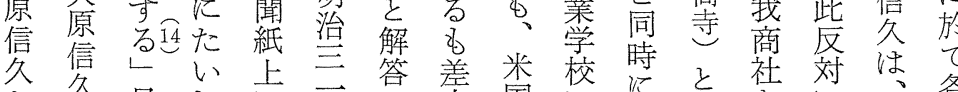

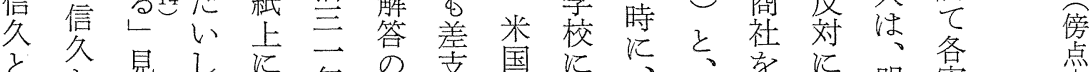

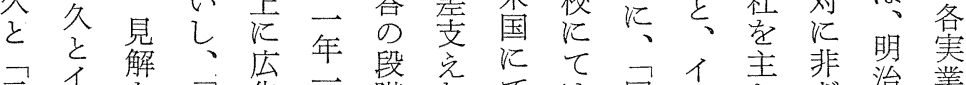

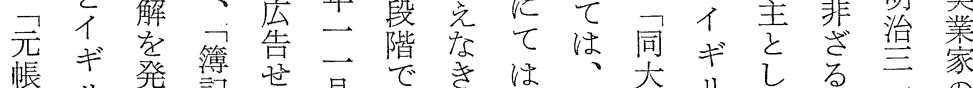

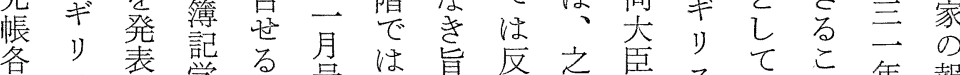
各勘 定式たの貝に閧答の刘紹式㝜明に告

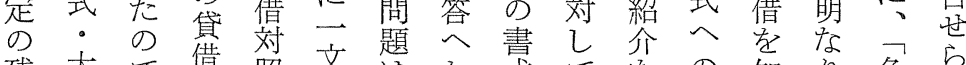
残大で借照文越た式てをの知り負。ら 残䔖 書い治用内世化行方等借る故はの きず量せ以と治負商対心゙に我を

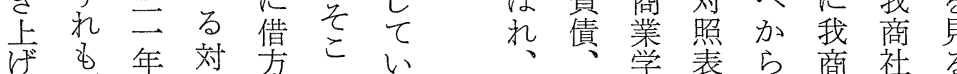
た可末末照資にな必貸校改导社の社る

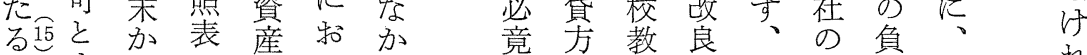
大 陸水治商、沓々島書貸勘方。之

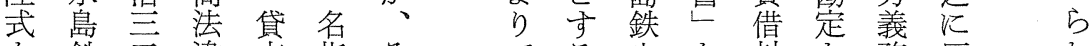
を鉄三違方指と年年対を務反 


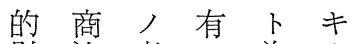
財 法考 天 為力 産上虑ル年将 貸於要ノ キ 又 方 テ ス 二 力 積

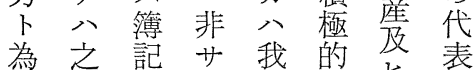
シト学 ル 新財損的 消同上さ旧産 極 シ 二小商交失解 的方於 公法七是以

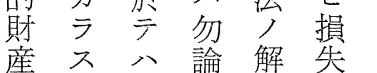
産爻再論解失 算 借于説り上以方等

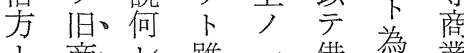
卜商。レ 雖 一借点業 為法。モ壬疑方消学 夕策。不主。問卢消 校 ル十。的。リ采的授

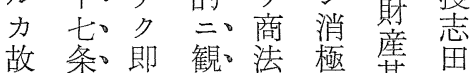
二三干察。三的其鉀 貸於貸方。所財他 太誢 対八而儿貸其二有 照貸 七名方他有解

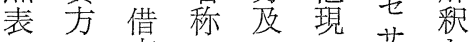

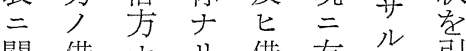
関借ナり借有心方

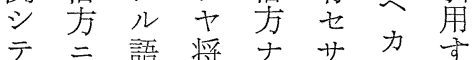
モ超八爷ルルラる 亦二全又語へサと 之ルク客、八力ル

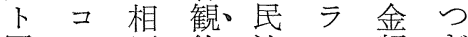
同卜反的法ラ額ぎ 一判対二。上文の ノ然 ス 観、少ル元と 解 ナル 察。所金利 特 橎ル二シ。謂額益り ヨ卜 様夕貸及等 採キノル借七以あ 用云用語卜利テり シ 皘卜法ナ同益借た 極謂りヤノ以下 的七ト 八意市為 財 積 雖 多義 貸 ス 産極モ少 $\ni$ 方へ
さ独し心こ然張雖是

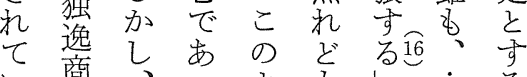
い亩、る た論当た

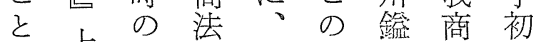
加卷商学第 論太 社太 ら巻法者一難郎学郎 も附学の回はと主な わ独者注の惜の立ら か独の意々し間しび る 逸解壱貸いに沉

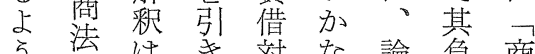
に歨法き势な 論真 商 文明汗表遂吕へ惊 旧の治、しに重利貸 商第三彼形決衫益借 法 第 严式戦 ら学苻 千百年に論に住点照 七十六刊のは号二はの 条二行問: ず 時 借 形 齐条さ題成己時方式

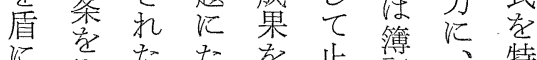
に文たた学步傅、特

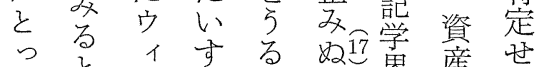
て

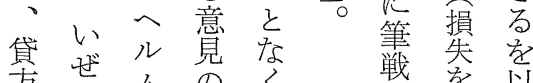

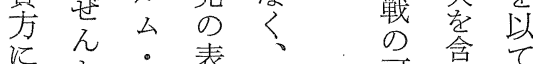
資と土表終可含导

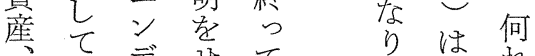
借》デせて长貸れ

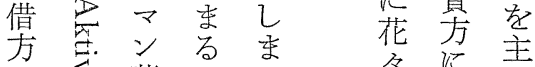
に允著々 ら 債 貸 堀 5 占 資: 秀産従 本 导 物 来 を壳郎学忌 揭窃・文の ぐ川古た問 べ借川 ら 題 乙方五し洦

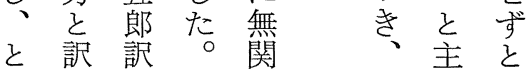


経営史学

入る

支の 払不学し年て大

の便元漸た二の臣

簿学帳 次大 云財に

記名

進ざびて 記 $\overrightarrow{0}$ 表 貸

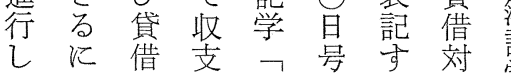

$つ$ 至対計校に ベ照校

れ照算に次望袁

あり、表簿 於再し 作

るレ゙通記即は貸具成長

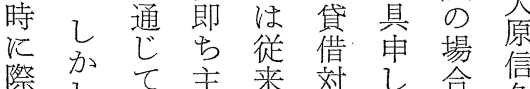

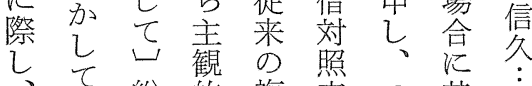

貸諸総的複表つ 式其

借諸の入簿就い方

の会場入記ててに

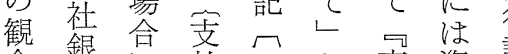

念行很貸

は㻜貸 $\vdots$ 名題 京 産 社

層其借資買方済利の

儥他 致 損 簿 論 雑 江貸

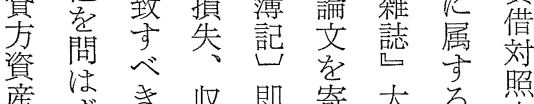

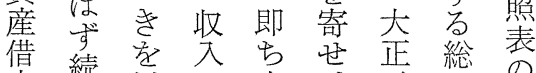

方続学

負従 芯貝観乞年只成

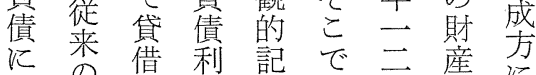

滴の借利記で晋産に

合式照复式貸治四記?

る 貸京踓改方四旦其

の方良負年な 借

あ 簿大教利東 び沉正

をよ陸授益京に省

認り式し簿可負年

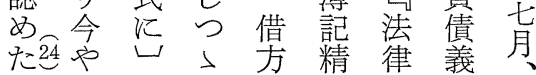

ᄂ 進顛市 ! 修新務

と先倒れ資学聞江今

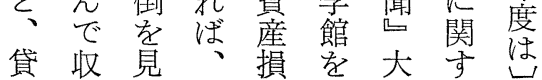

あ負第学て二不及 つ債一者 た と住に 見方っ大引輩レタ 出 即七原用公貸 学 ら踏信に意主方 有資襲久見観卜 寸 産さ る、れの開二シ も貸た20説る 陳観消 の方。皂よシ 察極 、即乙是 5 夕㔾的 而占加認皇にリサ財 乙負る宜儿産 て債にし商シへ其

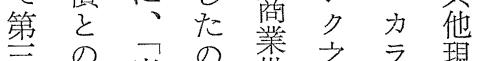
ほ の 光 の 党 之 借出時な界参ル有 方淁於占第罯十七

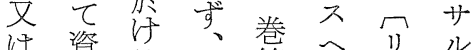
は資る、敢へリル

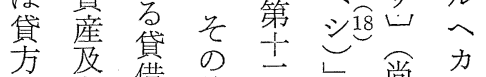
の負借後豆展 尚 両債照照号謗此 サ 語 照志論点紫 ル 省訳公鉀欄高亭金

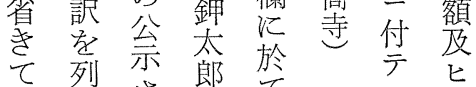
単挙さ即て 公損

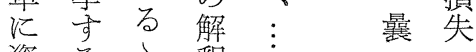

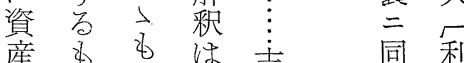
のの志文益

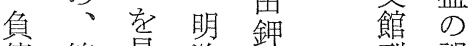
債第見治 太釬 刊誤 之三 口四郎行り 孚貸 見方凡代注業借 出即至比等 を ら三心法界。 用資様た律第為 ら産の方卡 サ る 形产 卷、 子借式で解 第 ル の21方市、釈士 が即り、商 と 
てにっ 无

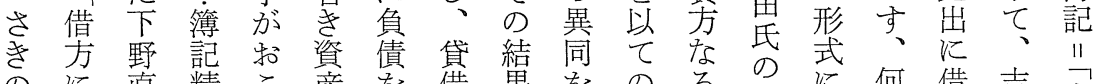
のに直精こ産怒借果を爻の方尤に何借吉大

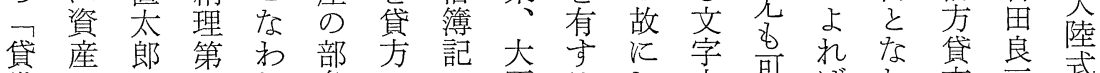

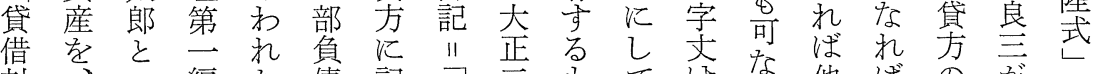
対、編 た債記 大至す 表照方 於と 部 せ 形負 貸

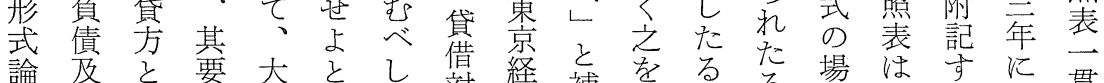

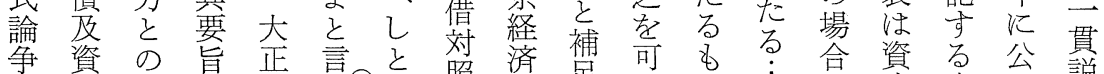

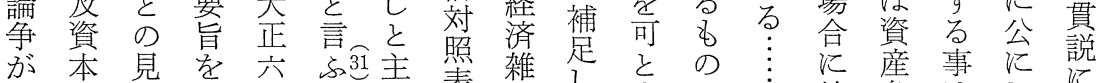

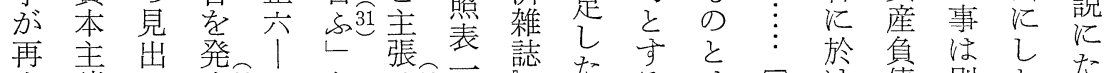

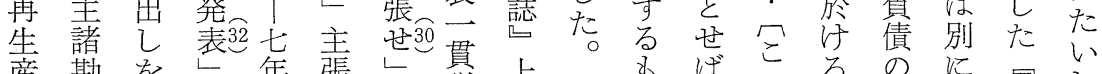
産勘劣

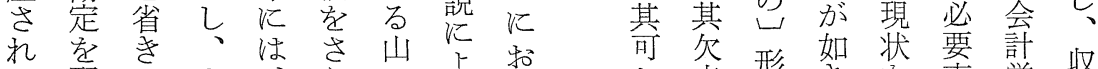

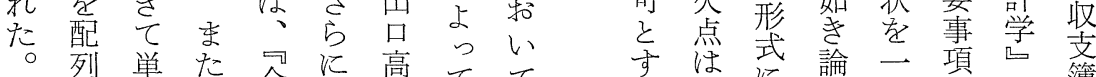

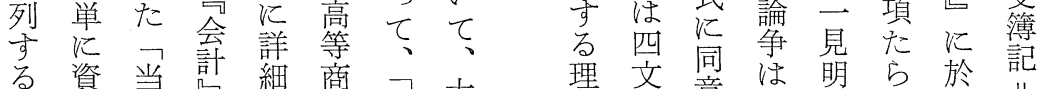

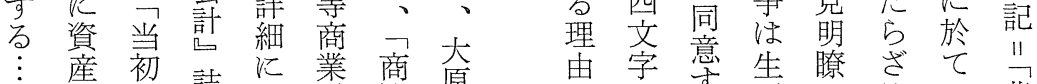

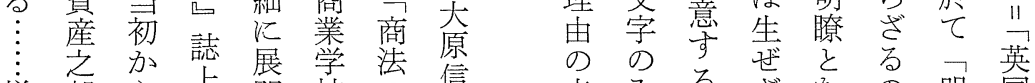
様 部ら 上開校告信点 み る

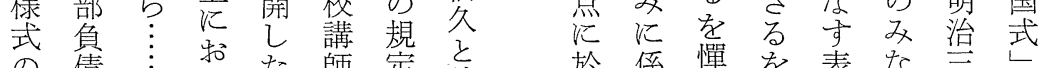

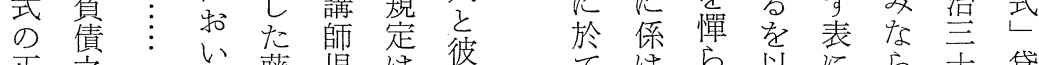

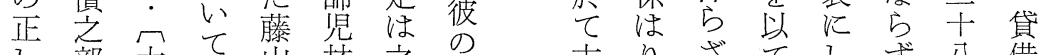
乙部大て山林之吉りざでず借 きと原与正百㞦支支其る便て理九対 こ為信疾々 合を舜簿也宜、論年照

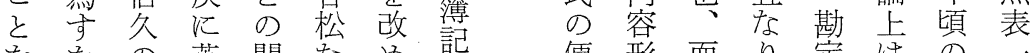
ををの英間な め記便形而り定はの 二 主可收国に方て 11 利式 6 と科却商貫

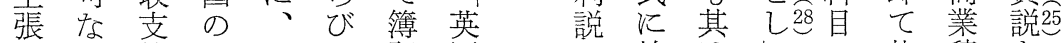

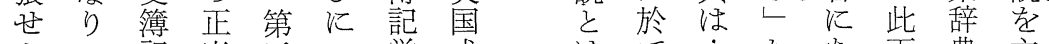

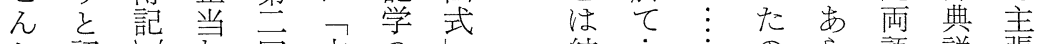
と認山局吉の結 $\vdots \vdots \vdots$ の す35識のるの田原貸果

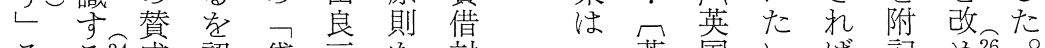

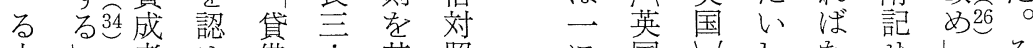
中し者め借 $\vdots$ 其照に国山しなせ 島 藤の 対 精 出 $\overrightarrow{33}$ 明照 に星人治表方罢説因異単信の以対さ

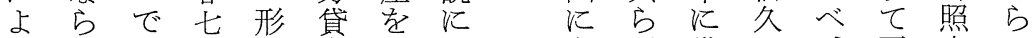
っびあ年式方借た、多ざ借は、正表に 
経 営史学

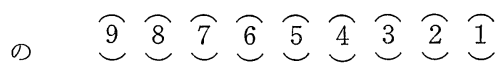
分占

な大大西松ブ箕商览上 に信信孝致 ! 麟編百

久久久治 $フ 7$ 祥筫合前

当つ可郎仏著. 局松揭

時貸実

の借地大商司井訳貸

ᄀ対応原法法憲口借八

銀照用信講省太瑟仏対四

行表簿久義訳郎国照ぺ

会の記著に 訳商表!

社誤学第仏法のジ

の謬教実三国仏復形

対 ᄂ 科地巻商国説式

照军書応

表東量用発略律書就

を京第簿行論提式て

参経一記年心要之一

考済巻学不明安部牙

の詰、教明治明 菒

為誌明科 、三治大京

め明治畫一○政済

比治西它三年三官済

乙三年簿ぺ五年蔵誌

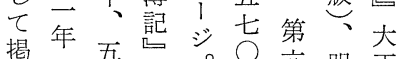

ぐ三忢昭 ペ六明正

犯云西和 I 快治年

左一四公至。公二

の 1 年四年月

日如昌八

如号涪四 ペ一日

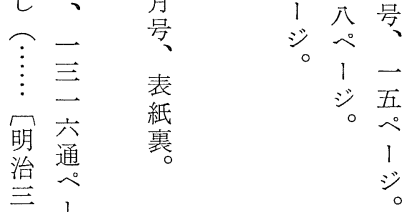

で上にのす第昧於

あの、訳べ七す す

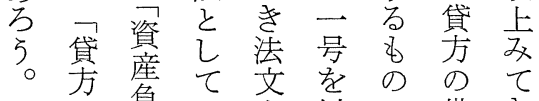

・負て 文を学

借責資の趑な方た

方表産根山少に方

と負势正此超

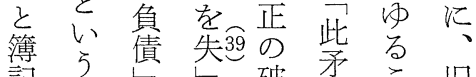

記

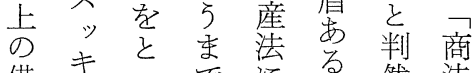

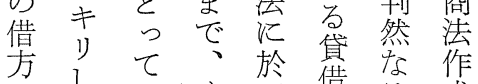

-しいく於借なる作

貸た たり

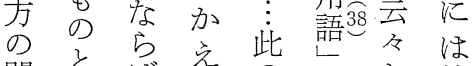

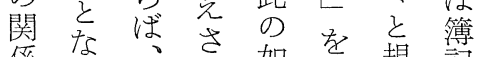

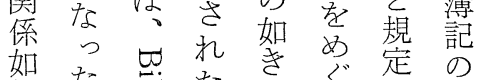

荷た导た机条ぐ定の

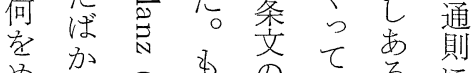

め) 少 も

ぐで氖し 踏貸を適

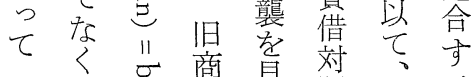

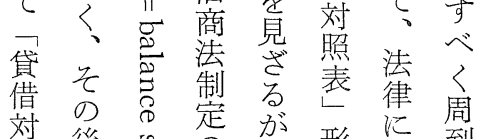

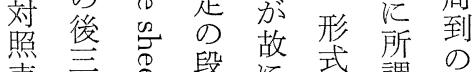

表吉呑段湝式謂 用

形余 訳借 $\vdots$ 争 貸意

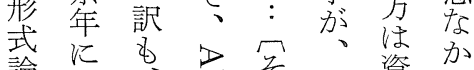

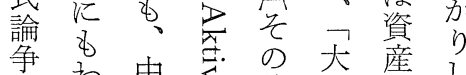

争わ中 字後正鏟改

加た語き岂艺意た

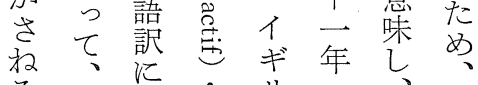

無貸名它光四借同

䭾借文怘. 式月方法

女対 5 岕形二は示

は照れ 式五負十

ぶ表る密を王㥽七

汗占虫主法学条

た法方㤁張律意に 
第 2 巻第 2 号

$\overparen{12} \overparen{11} \overparen{10}$ 表 是

下大大就依丙乙甲

野原原て り

直信信七て

太久久法之

郎貸水律孛

貸借島新れ

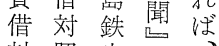

対照也大。

照表氏正七

表に就貸元公

形七借年 以去百

学照照に五三五

論律表当は

ず新学

茼境昆其

会电号其

棓昰商一数

大元業四总

正年世 ゚゚ 占

六一界! た

年○汇县る

四旦明丙

号 治 種

、 三 形

四号年式

ペ三 減

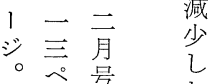

$1 、$ た

涪吾こ

皆明

1 5

か

な

?

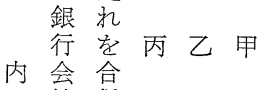

社 併

総 ᄂ

計

绫

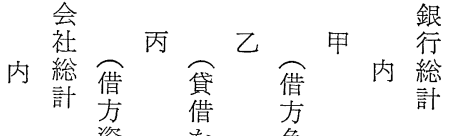

武

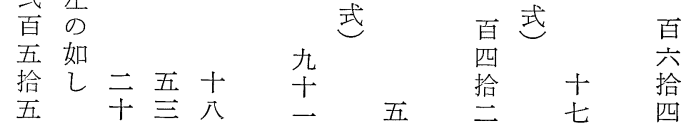

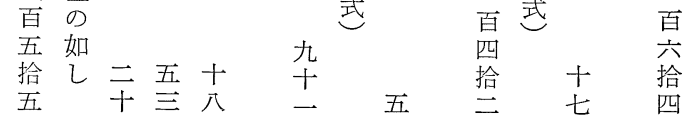

資学 負

附債

ぜ貸

$\begin{array}{lll}\text { 方 } & \text { 方 } \\ \text { 負 る } & \text { 資 }\end{array}$

㥽式圱

.

多




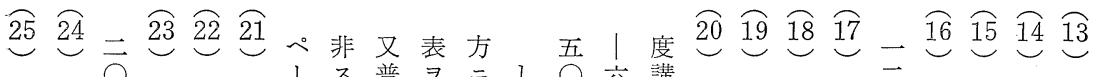
こ右日大大東ジ破通無資かペペ義志大志東月森兼右水 の掲号原原、産, 効産乙1 1 録田原田瞆二川子揭島 収論、信、前と二観ナノ、ジジし鉀、、五四鋝初論鉄 支文五久前揭、関念り方大、。一 太前前郎日太态文也 簿、ペᄀ揭書いス二卜面正参青八郎揭揭口号郎郎、 記三। 再論、わ儿於断三年照山八可論書商、水一貸

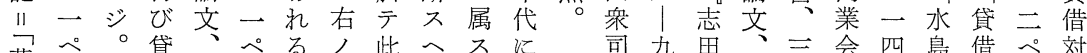
英ぺ。貸、ペるく此へスに

国 1 借三lよ規ノキル入

式浚対三照ペ。定如三財る

貸七。表! 施付解然項旧

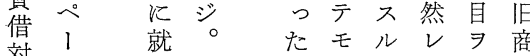

照济势形 7 共揭法

説

は

さே

す

第

回

售

対

照

表

形

式

論

の

際

そ

抒

け

る

大、聞

原、大

君、正

議、年

$\begin{array}{ll}\text { 論、 } & \text { 三 } \\ \text { 是、 }\end{array}$
式穏旧ク千

二当商ル十

拘 卜 法 ב 七

泥又第卜条

セへーアの

サシ $○$ 解

儿但一下积

解 シ七スは

釈之条ル弾

寻无力

下穏破或的

サ当産公と

サ卜編又な

ル片, 光り

力八如区例

ラミキ対例

ス之公明心

片違貸法方

山不方律二

義ル $\Rightarrow$ 論 㥽

勝力積卜務

品為極シ，

商メ財テ方

法 二 産八面

総 対, 之 =

則照 意 $\ni$ 属

論表義理 ス

し

大 無 用卜財

正効 キ シ 産

至卜夕学

、規貸

三 モ定借揭

五人二対尔

九 テ 照借
吃氏一三計三大対 1 照

商1 商四三匹八原照 ジ表

法ジ法ペ门第通三表。を

総。要 1 三一ペ氏 $氏$ 論

則青義ジぺ輯! の誤ず

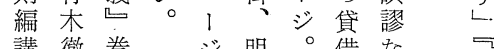

講徹巻ジ明。供な商

義二 之

明商

治法明

三総 治

七論三

年此六

、明年

五菭一

四六五

年杂

五一ペ

1 五 ジ

ジ九 卆。

青

条潦本

徹松治

可本商

商烝阔

法治法

総口毓

論 商則

法瓜

訂論仏

三七法

版 明 律

、治学

明 三校

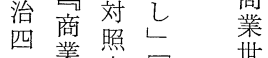

一業表啨世

年世界論菒界

三芯並経 明

忈明告済治

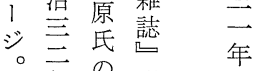

年当明年

月㝧治百

五金筫 号

号通年二 七

分関刍 证

治 苜的

○、治

年 三 京

二五年
ペす

1る日

澺号

読 二

読 三

む七

菓通

京 ペ

経

済 シ

雑

誌

明

治

三

年 


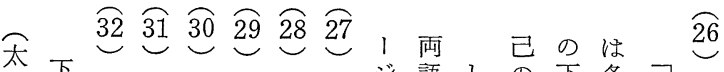

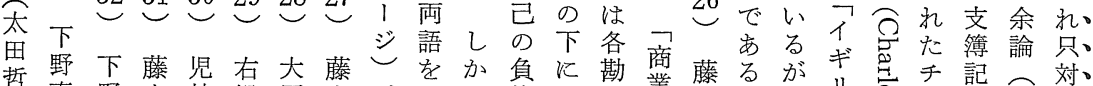

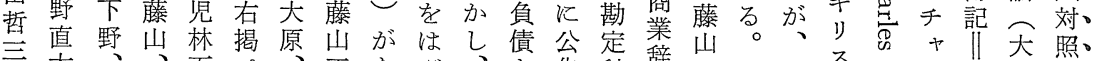

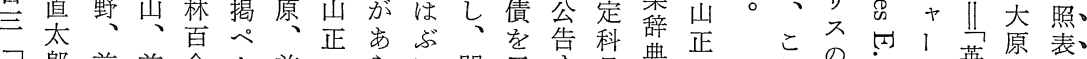

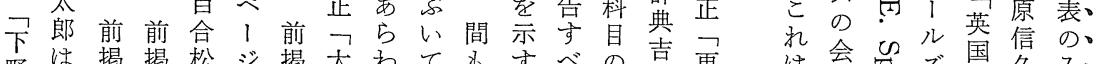
会明論論フ。論原れ単なをき貸田び

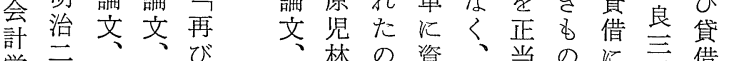

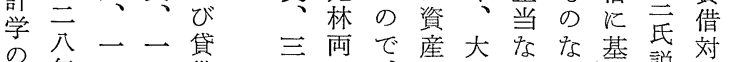

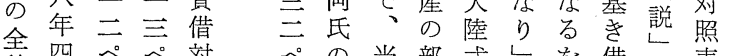
貌四ぺ效吕の当部式しを借子表

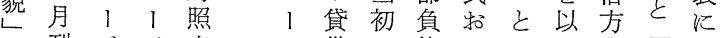
会の刊涪表借の倩よのて資は就 竐簿七照を説のび部イ 昭簿式资表改とギ論会乞元余

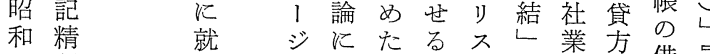

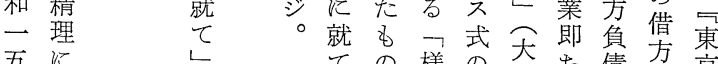

年 於 ての様の大原占責方景

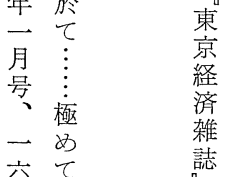

空尔

1 単

艺で

ばあ

かる

り

で

英

明 国

治 式

公 貸

| 対

九 照

年表

ᄀ袁

大 説

日 明

本 2

実て

業い

学る

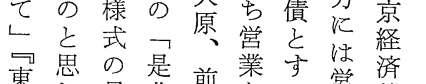

現䜊 金冓票 $\mathrm{E}$ 貸答応。 支家 方借答用。 計は齐弪対しべ。

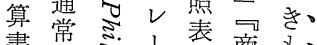

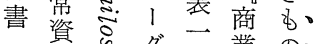

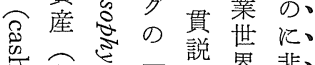

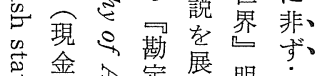

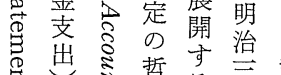
总出哲す产君

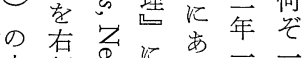
本側是飞た南步

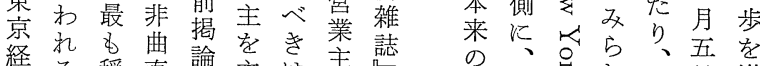

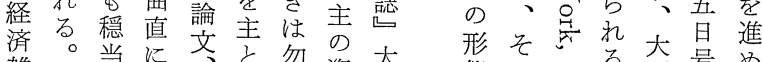

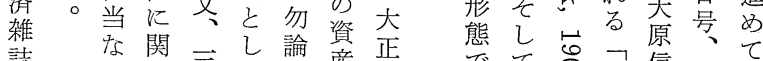

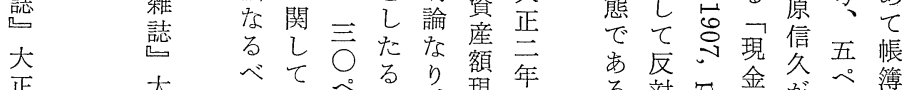

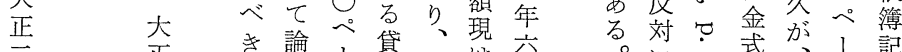

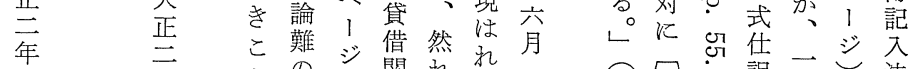

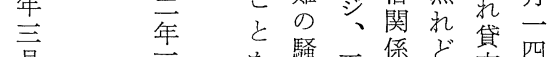
点負訳艺法 倩々理 0 占改 子資元年 5 良 及本只总提を るす英唱言主 な国吉治答せ 見占式恶四克 解現貸の年たる を金借の会のや 知收対会に究に 口照貸二思承 てを表借こ思永 い左㕜愔 1 わ島 た側位照 ヨれ也 か儿置照！。他 ぞ配げへ命でた貸 㤎置るの応出じ借 不乙|用版、照 明て过さ収表 


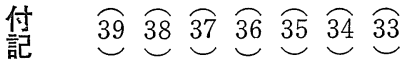

初るで

本上藤児藤中藤下郎き店 $て$

稿野山林山島山野氏も勘簿

は、百正精正直にの定記

一 前 前合

九揭揭松再 貸郎ふし貸を

六書論一び借借つレて方講

六文貸貸方対收菓、述

年八、借借貸照支柰借はし

二 五三文姇方表簿京方当た

経棌、表表意用法済

営さジ就就をを諭誌店し其

てて諭諭ず明の借う

果虫でずし治負主

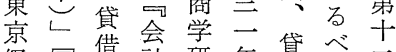

経古借梳研年貸ぎ主

済菒驽照究二方き回

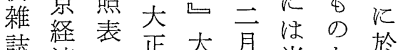

誌競の正大月当を於

大雑形六正元店列?

大誌式年可百举

正䐴江年号資与

年大及号二号産る

正步

公年二五年四举り

日公しペ产す当

号月可 1 通る然店

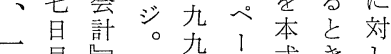

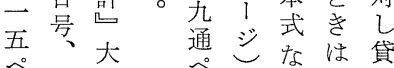

ペ—正ぺしなは貸

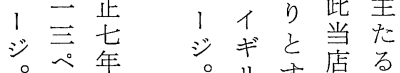

1 三 ○氘占る

ジ月式子定き

式を定き

主言 炎の

四主長を当を

㤩張学点当

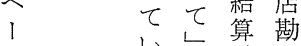

ジ。

京
都
学
学

原報借

信 告 方

久

兼式而

兼式而 


\title{
The Controversy over Forms of Balance Sheet in Meiji Japan
}

\author{
by \\ Sadao Takatera \\ University of Kyoto
}

The system of publicizing business balance sheets was introduced to Japan early in the Meiji period on two separate occasions. When the government transplanted the National Bank system from the United States to Japan, in the years 1873-75, it attempted to institutionalize financial statements as a means of controlling the activities of the new National Banks in Japan. Again, in 1883, in the course of introducing continental commercial law to Japan, the French and German system of financial statements was adopted as the core of the accounting system required by the new law.

In the interval the British form of balance sheet prevailed, under the influence of the Meiji government, and terms such as karikata ("debtor") or fusai-gimu ("liabilities and obligations"), and kashikata ("creditor") or shisan" kenri ("assets and claims") were prevalent. When the Continental system was applied, the term actif=Passiva, which properly meant "asset," and the term passif=Passiva, which meant "liability", were translated respectively as kashikata $(\mathrm{Cr})$ and karikata (Dr). These translations were authorized and established by the first commercial law, issued in 1890. Consequently, in spite of the application of the Continental form of balance sheet which listed the assets on the left hand and the liabilities and obligations on the right, the British form which listed the liabilities and capital on the left hand and the assets on the right had to be followed according to the commercial law.

The two forms of balance sheet, Continental and British, continued to be valid side by side until the system was unified following the Continental pattern in the middle of the Taisho period, and the commercial law revised 
in 1922. In the meantime, however, debates on the appropriate form of balance sheet were frequent between the two schools, British and Continental. The controversy was similar to the dispute which arose among British accountants at the beginning of the 20th century concerning Table B of the Company Act of 1862.

\title{
The Cotton Textile Industry in Northern New England: A Case Study of Amoskeag Manufacturing Company
}

\author{
by \\ Kesaji Kobayashi \\ Ryukoku University
}

This paper deals with a cotton manufacturing company in Manchester, New Hampshire, promoted by a group of entrepreneurs known as the "Boston Associates."

Started as a small establishment in the 1830's, this company had grown in the space of a century to one of the largest-scale and highest quality companies in the industry. But though the mills in Manchester were firmly establi shed, the management of the company in Boston was totally unsuited to meeting the changing situation in the early 20th century. One of the causes of the company's bankruptcy in the 1930's was attributed to mismanagement by the executives.

With an emphasis on the functions, respectively, of the company treasurer and of the local mill agent, this paper analyzes the relationship between decision-making and execution, and discusses some of the characteristics of business enterprises controlled by the so-called general entrepreneurs of 19 th century America. 